\title{
Emission, transport, and radiative effects of mineral dust from the Taklimakan and Gobi deserts: comparison of measurements and model results
}

\author{
Siyu Chen ${ }^{1}$, Jianping Huang ${ }^{1}$, Litai Kang ${ }^{1}$, Hao Wang ${ }^{1}$, Xiaojun $\mathrm{Ma}^{1}$, Yongli $\mathrm{He}^{1}$, Tiangang Yuan ${ }^{1}$, Ben Yang ${ }^{2}$, \\ Zhongwei Huang ${ }^{1}$, and Guolong Zhang ${ }^{1}$ \\ ${ }^{1}$ Key Laboratory for Semi-Arid Climate Change of the Ministry of Education, Lanzhou University, Lanzhou, China \\ ${ }^{2}$ School of Atmospheric Sciences, Nanjing University, Nanjing, China
}

Correspondence to: Jianping Huang (hjp@lzu.edu.cn)

Received: 17 June 2016 - Discussion started: 3 August 2016

Revised: 25 December 2016 - Accepted: 22 January 2017 - Published: 15 February 2017

\begin{abstract}
The Weather Research and Forecasting Model with chemistry (WRF-Chem model) was used to investigate a typical dust storm event that occurred from 18 to 23 March 2010 and swept across almost all of China, Japan, and Korea. The spatial and temporal variations in dust aerosols and the meteorological conditions over East Asia were well reproduced by the WRF-Chem model. The simulation results were used to further investigate the details of processes related to dust emission, long-range transport, and radiative effects of dust aerosols over the Taklimakan Desert (TD) and Gobi Desert (GD). The results indicated that weather conditions, topography, and surface types in dust source regions may influence dust emission, uplift height, and transport at the regional scale. The GD was located in the warm zone in advance of the cold front in this case. Rapidly warming surface temperatures and cold air advection at high levels caused strong instability in the atmosphere, which strengthened the downward momentum transported from the middle and low troposphere and caused strong surface winds. Moreover, the GD is located in a relatively flat, high-altitude region influenced by the confluence of the northern and southern westerly jets. Therefore, the GD dust particles were easily lofted to $4 \mathrm{~km}$ and were the primary contributor to the dust concentration over East Asia. In the dust budget analysis, the dust emission flux over the TD was $27.2 \pm 4.1 \mu \mathrm{g} \mathrm{m}^{-2} \mathrm{~s}^{-1}$, which was similar to that over the GD $\left(29 \pm 3.6 \mu \mathrm{g} \mathrm{m}^{-2} \mathrm{~s}^{-1}\right)$. However, the transport contribution of the TD dust (up to 0.8 ton $\mathrm{d}^{-1}$ ) to the dust sink was much smaller than that of the GD dust (up to 3.7 ton $\mathrm{d}^{-1}$ ) because of the complex terrain and the prevailing wind in the
\end{abstract}

TD. Notably, a small amount of the TD dust $\left(\mathrm{PM}_{2.5}\right.$ dust concentration of approximately $8.7 \mu \mathrm{g} \mathrm{m}^{-3}$ ) was lofted to above $5 \mathrm{~km}$ and transported over greater distances under the influence of the westerly jets. Moreover, the direct radiative forcing induced by dust was estimated to be -3 and $-7 \mathrm{~W} \mathrm{~m}^{-2}$ at the top of the atmosphere, -8 and $-10 \mathrm{~W} \mathrm{~m}^{-2}$ at the surface, and +5 and $+3 \mathrm{~W} \mathrm{~m}^{-2}$ in the atmosphere over the TD and GD, respectively. This study provides confidence for further understanding the climate effects of the GD dust.

\section{Introduction}

Dust is regarded as a major component of tropospheric aerosols in the global atmosphere (Forster et al., 2007; Zhang et al., 2003; Bi et al., 2011) and is considered to have a significant direct effect on climate by altering the radiative balance between the incoming solar and outgoing planetary radiation in the atmosphere (Ramanathan et al., 2001; Huang et al., 2008a, b, c, 2009, 2010, 2011; Fu et al., 2009; Han et al., 2012; Zhao et al., 2013; Chen et al., 2014a, b). In addition, dust can indirectly modify the microphysical properties of clouds by influencing cloud condensation nuclei and ice nuclei and thus influence precipitation efficiency (Koren et al., 2004; Huang et al., 2006a, b, c, 2010, 2014; Su et al., 2008; Qian et al., 2009; Li et al., 2010). Therefore, dust aerosols play important roles in changing the energy budget and atmospheric and hydrological systems at regional and even global 
scales (Wang et al., 2010, 2012; Huang et al., 2010, 2014; Li et al., 2011; Zhao et al., 2011, 2012).

East Asian dust is entrained from China and its surrounding regions, which constitute the second largest contributor to global dust aerosols (Rea, 1994; Zhang et al., 2003; Ye et al., 2012). The Taklimakan Desert (TD) and Gobi Desert (GD) are two major dust source regions in East Asia (Fig. 1a) (Sun et al., 2001). The TD is the location of the second largest shifting sand desert in the world and covers an area of $337000 \mathrm{~km}^{2}$, approximately $85 \%$ of which is covered by shifting sand dunes (Ge et al., 2014). It is located in the Tarim Basin and is surrounded by the Kunlun Shan Mountains (average elevation $5.5 \mathrm{~km}$ ) to the south, the Tianshan Mountains (average elevation $4.8 \mathrm{~km}$ ) to the north, and the Pamir Plateau (average elevation $5.5 \mathrm{~km}$ ) to the west. The GD covers parts of northern China, northwestern China, and southern Mongolia, and is bounded by the TD in the west, the North China Plain in the southeast, and the Hexi Corridor and Tibetan Plateau in the southwest.

Airborne dust over the TD may play an important role in the global radiative energy budget (Huang et al., 2009, 2015). Special efforts have been dedicated to understanding the spatial and temporal features of the TD dust (Liu et al., 2016), including emission (Zhang et al., 2003; Zhao et al., 2003, 2006a; Shao et al., 2011; Chen et al., 2013, 2014a; Xiong et al., 2013), long-range transport (Uno et al., 2001; Han et al., 2005, 2006, 2008; Zhao et al., 2006b, 2007; Huang et al., 2007), radiative forcing (Takamura et al.,2004, 2005; Su et al., 2008; Huang et al., 2009; Ye et al., 2012), and its climatic effects (Huang et al., 2006a, b, 2007, 2010, 2014) over the TD. However, few of these studies have investigated the role of GD dust in the earth-atmosphere system, especially concerning the differences and similarities in the dust emission and transport over the GD and TD. Using dust storm reports from 1960 to 1999, Sun et al. (2001) found that the $\mathrm{GD}$ is the dominant dust source region for East Asia. The dust is deposited over East Asia including the Loess Plateau in China and offshore regions. Using Cloud-Aerosol Lidar and Infrared Pathfinder Satellite Observation (CALIPSO) retrievals and surface measurements, Huang et al. (2008) found that dust events are more frequent over the TD, where suspended dust was dominant locally, whereas GD dust storms were less frequent but more intensive. Zhang et al. (2008) showed that the GD accounted for more than $75 \%$ of the dust emission events in all of East Asia using time series of Multi-Angle Imaging SpectroRadiometer (MISR) images. However, it is difficult to use observational data to quantify the details of TD and GD dust emission fluxes and to distinguish the contributions of the TD and GD to dust transport in the downwind deposition regions of East Asia.

In this study we used a state-of-the-art model that simulates detailed dust processes to investigate a typical dust event over East Asia that occurred on 18-23 March 2010. This dust storm was the strongest since 2006 in terms of its scope, intensity, and duration. It swept across almost
21 provinces in China, covering an area of $282 \times 104 \mathrm{~km}^{2}$ and affecting approximately $2.7 \times 10^{8}$ people. Dust particles even underwent long-range transport to Shenzhen, Hong Kong, and Taiwan. Due to the strong influence of this storm, Hong Kong reported an air pollution index that exceeded 400 , and Shenzhen also experienced a heavily polluted day on 19 March 2010 (Li et al., 2012). The aim of this work was to (1) evaluate the ability of the Weather Research and Forecasting Model with chemistry (WRF-Chem model) to reproduce East Asian dust relative to observational data, (2) investigate the dynamic and thermodynamic mechanisms of dust emission and transport over the TD and GD, (3) elucidate the influence of TD and GD dust throughout East Asia, and (4) estimate the direct radiative forcing induced by the TD and GD dust over East Asia. The paper is organized as follows. The model and observational data are described in Sects. 2 and 3. The model evaluation and a discussion of the emission and transport of East Asian dust are presented in Sect. 4. The radiative forcing of dust is estimated in Sect. 5, followed by the discussion and conclusions in Sect. 6 .

\section{Model description}

The WRF-Chem model, which simultaneously simulates trace gases, particulate materials, and meteorological fields (Skamarock et al., 2008), was used in this study. Gas-phase chemical mechanisms, photolysis schemes, and aerosol schemes are incorporated into the WRF-Chem model, which considers a variety of coupled physical and chemical processes such as emission, transport (advection, diffusion, and convection), dry/wet deposition, chemical transport, aerosol interactions, and the radiation budget (Grell et al., 2005). Compared with other numerical models, the "online" coupling of meteorology and chemistry in the WRF model more accurately represents the evolution of trace gases and aerosols and permits the inclusion of detailed feedback processes for weather or climate changes. Details of the model and relevant references can be found at http://www.pnl.gov/atmospheric/research/ wrf-chem/ and http://www.pnl.gov/atmospheric/research/ wrf-chem/publications.stm, respectively.

The Regional Acid Deposition Model version 2 chemical mechanism, and the combination of the Model Aerosol Dynamics Model for Europe (MADE) with the Secondary Organic Aerosol Model (SORGAM) (referred to as MADE/SORGAM) (Ackermann et al., 1998; Schell et al., 2001), were integrated by Grell et al. (2005) into the WRFChem model. The MADE/SORGAM model uses the modal approach with Aitken, accumulation, and coarse modes to represent the aerosol size distribution. The aerosol species include mineral dust, sulfate, nitrate, ammonium, black carbon, organic compounds, and sea salt. Aerosol optical properties (e.g., single-scattering albedo, asymmetry factor, and extinction) are computed as a function of wavelength. Furthermore, 


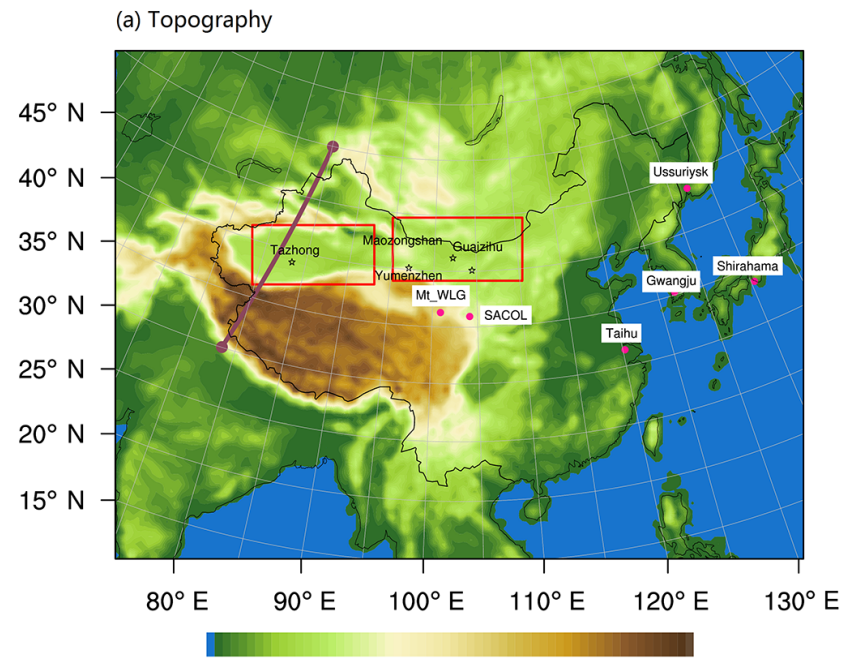

2011001180126013401420150015800 (b) Erodibility

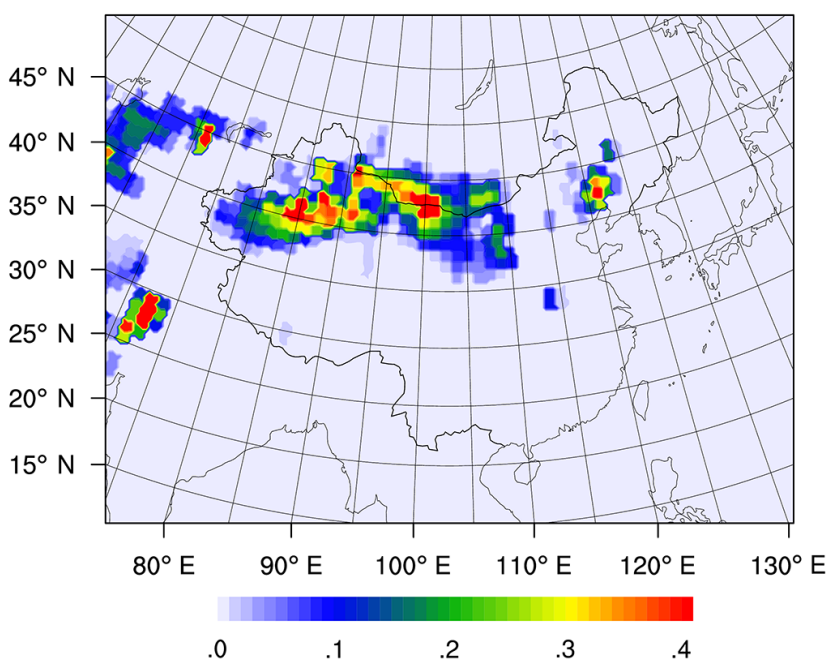

Figure 1. (a) Modeling domain and spatial distribution of the topography over East Asia. The Taklimakan Desert (TD) and Gobi Desert (GD) are indicated by the red boxes. The pink dots are the AERONET sites (SACOL, Mt. Waliguan (Mt_WLG), Taihu, Gwangju_GIST, Shirhuma, and Ussuriysk). The black stars are the sites with observed $10 \mathrm{~m}$ winds (Tazhong, Maozongshan, Yumenzhen, and Guaizihu). The brown line represents the orbit path of CALIPSO/CALIOP over the TD at 00:08 UTC (02:08 LT) on 19 March 2010. (b) Soil erodibility used in the GOCART dust emission scheme for the WRF-Chem model.

each chemical constituent of the aerosols is associated with a complex index of refraction (Barnard et al., 2003).

The Goddard Chemistry Aerosol Radiation and Transport (GOCART) dust emission scheme (Ginoux et al., 2001) was coupled with MADE/SORGAM in the WRF-Chem model (Zhao et al., 2010). Additional details about the GOCART dust emission scheme in the WRF-Chem model can be found in Chen et al. (2013, 2014a). An emission inventory of anthropogenic, biomass burning, biogenic, and volcanic emissions is also included in the simulation. The anthropogenic emissions of carbon monoxide, nitrogen oxides, $\mathrm{SO}_{2}$, volatile organic compounds, black carbon, organic carbon, $\mathrm{PM}_{2.5}$, and $\mathrm{PM}_{10}$ were taken from the 2006 emission inventory developed by David Street (http://www.cgrer.uiowa. edu/EMISSION_DATA_new/index_16.html). The biomass burning emissions were obtained from the Global Fire Emissions Database, version 3, and have a monthly temporal resolution and $0.5^{\circ}$ spatial resolution (van der Werf et al., 2010).

Figure 1a illustrates the modeling domain which covered the entirety of East Asia $\left(10.8-59.6^{\circ} \mathrm{N}, 51.9-154.3^{\circ} \mathrm{E}\right)$ with a horizontal grid interval of $36 \mathrm{~km}$ and $138 \times 187$ grid cells. This domain covered the dust source regions over East Asia, represented by erodibility in the WRF-Chem model, as shown in Fig. 1b. The model atmosphere was divided into 35 vertical layers, and the top pressure of the model was $100 \mathrm{hPa}$. To reduce the computational time required for the simulation, the integration period was 1-23 March 2010. Only the results from 18 to 23 March 2010 were used in this study (hereafter referred to as the simulation period). The initial and boundary meteorological conditions were con- structed from the National Center for Environmental Prediction Final Analysis (NCEP/FNL) data at a $6 \mathrm{~h}$ temporal interval and $1^{\circ}$ horizontal resolution. The NOAA land surface model (Chen et al., 1996; Chen and Dudhia, 2001) and the Yonsei University planetary boundary scheme (Hong et al., 2006) were used in the simulation. The Morrison twomoment microphysics scheme (Morrison et al., 2005) and the Kain-Fritsch convective scheme (Kain et al., 1990; Kain et al., 2004) were also used to represent cloud microphysics and convection processes (Zhao et al., 2013) in the simulation. To produce a more realistic simulation of the large-scale circulation and main weather systems, the modeled $u$ - and $v$-wind components and atmospheric temperatures were nudged towards the NCEP/FNL data with a nudging timescale of $6 \mathrm{~h}$ (Stauffer and Seaman, 1990).

\section{Observations}

\subsection{CALIPSO aerosol extinction coefficients}

The aerosol extinction profiles retrieved by the CALIPSO satellite were used in the study. The CALIPSO satellite, launched in April 2006 to investigate the vertical structure of aerosols and clouds, carries the Cloud-Aerosol Lidar with Orthogonal Polarization (CALIOP) instrument (Winker et al., 2006, 2007). In this work, the observed aerosol extinction from the CALIPSO level 2 cloud and aerosol profile products at $5 \mathrm{~km}$, version 3.3 , was analyzed. The retrievals were used to evaluate the simulated vertical structure of dust particles along the orbital path at 20:08 UTC on 19 March 2010 in the 
Table 1. Information on the $10 \mathrm{~m}$ wind stations from the Chinese National Meteorological Center (CNMC).

\begin{tabular}{lrrr}
\hline Name & $\begin{array}{r}\text { Latitude } \\
\left({ }^{\circ} \mathrm{N}\right)\end{array}$ & $\begin{array}{r}\text { Longitude } \\
\left({ }^{\circ} \mathrm{E}\right)\end{array}$ & $\begin{array}{r}\text { Elevation } \\
(\mathrm{m})\end{array}$ \\
\hline Tazhong & 39.00 & 83.40 & 1099.3 \\
Guaizihu & 41.22 & 102.22 & 960.0 \\
Yumenzhen & 40.16 & 97.02 & 1527.0 \\
Maoyinbadao & 40.10 & 104.18 & 1325.9 \\
\hline
\end{tabular}

study. The data on clouds and stratospheric features based on the atmospheric volume description and cloud aerosol discrimination score were screened (Liu et al., 2004). Features with cloud aerosol discrimination scores exceeding 80 were selected for this work, providing confidence in the classification of dust layers using the CALIOP cloud-aerosol discrimination algorithm.

\subsection{Aerosol Robotic Network (AERONET) aerosol optical depth (AOD)}

AERONET is a global ground-based aerosol monitoring network established by the National Aeronautics and Space Administration, and the photometry data for the operational satellite processing standards of the National Center for Scientific Research obtained from standardized automatic sun photometers that measure the sun and sky radiance at several wavelengths in the visible and near-infrared bands. The observed radiances are further processed to retrieve the aerosol properties via algorithms developed by Dubovik and King (2000) and Dubovik et al. (2002). The global AOD is provided in near real time after calibration, processing, and distribution. AOD data products are available at three levels based on data quality: unscreened data (Level 1.0), cloud-screened data (Level 1.5), and qualityassured and cloud-screened data (Level 2.0). In this work, the Level 2.0 products of the AOD at the SACOL, Mt. Waliguan (Mt_WLG), Taihu, Gwangju_GIST, Shirhuma, and Ussuriysksites (Fig. 1a and Table 1) sites were used to evaluate the simulated AOD over the dust source regions and remote regions.

\section{Results and discussion}

\subsection{Meteorological conditions}

To evaluate the model performance in simulating dust emission and transport during the dust storm event, we first compared the simulated meteorological conditions with the reanalysis data and in situ measurements. The average wind and temperature fields at $500 \mathrm{hPa}$ from the NCEP/FNL reanalysis data and WRF-Chem simulations over East Asia during the simulation period are shown in Fig. 2. Generally, the WRF-Chem model reproduced the large-scale circulation field over East Asia extremely well, including the location and shape of the East Asian subtropical westerly jet stream, the lower-latitude edges of the westerly jet, and the upperlevel westerly jet over East Asia (Fig. 2a). The WRF-Chem model was able to simulate the wind speed well over the TD, GD, and eastern and southern China, where the differences from the observations were only $-0.6-0.6 \mathrm{~m} \mathrm{~s}^{-1}$. The wind speed over the surrounding area of the Tibetan Plateau (TP) was overestimated at $1.2-3 \mathrm{~m} \mathrm{~s}^{-1}$ due to the complex terrain (Fig. 2b). The differences in temperature at $500 \mathrm{hPa}$ between the WRF-Chem model and NCEP/FNL reanalysis data over East Asia are also demonstrated in Fig. 2d. In general, the simulated temperature was almost consistent with the reanalysis data, especially in eastern, southern, and northwestern China. Slightly underestimated values $\left(-0.4\right.$ to $\left.-0.6^{\circ} \mathrm{C}\right)$ existed over the GD and extended to the surrounding areas of the TD. Moreover, the WRF-Chem model could not simulate the air temperature at $500 \mathrm{hPa}$ over the TP well. The bias reached $-1.3^{\circ} \mathrm{C}$ on the northern slope of the TP, which is beyond the scope of this study.

Wind rose diagrams for four meteorological stations, including Tazhong over the TD and Guaizihu, Yumenzhen, and Mazongshan over the GD (Fig. 1a and Table 1), are shown in Fig. 3. The hourly $10 \mathrm{~m}$ wind observations were obtained from the Chinese National Meteorological Center and will be referred to as the observed wind direction and wind speed records. The winds mainly blew from west to east at the Tazhong site during the dust event. The wind speeds generally exceeded $2 \mathrm{~m} \mathrm{~s}^{-1}$. The frequency of calm winds accounted for $8.0 \%$ of the total wind records. The average magnitude of the observed wind speed at the Tazhong site $\left(3.4 \mathrm{~m} \mathrm{~s}^{-1}\right)$ was lower than the average value in the simulations $\left(5.2 \mathrm{~m} \mathrm{~s}^{-1}\right)$. Over the GD, the wind speeds were primarily between 3 and $10 \mathrm{~m} \mathrm{~s}^{-1}$, and the average wind speed exceeded that at the Tazhong site. At the Guaizihu site, the prevailing wind direction was from the west and the northwest, and the simulated wind speed was slightly higher than the observed wind speed. At the Yumenzhen site, the prevailing wind direction was generally from the east, and the simulated wind speed $\left(6.4 \mathrm{~m} \mathrm{~s}^{-1}\right)$ was higher than the observed wind speed $\left(4.7 \mathrm{~m} \mathrm{~s}^{-1}\right)$. At the Mazongshan site, located west of the Guaizihu site, the simulations did not capture the easterly component of the winds well.

Generally, the WRF-Chem simulations reproduced the wind field at the surface in the dust source regions. However, the simulated wind speed at $10 \mathrm{~m}\left(4.2 \mathrm{~m} \mathrm{~s}^{-1}\right.$ over the TD and $6.4 \mathrm{~m} \mathrm{~s}^{-1}$ over the GD) was slightly higher than the observed wind speed $\left(3.5 \mathrm{~m} \mathrm{~s}^{-1}\right.$ over the TD and $\left.5.7 \mathrm{~m} \mathrm{~s}^{-1}\right)$. In addition, the frequency of calm winds in Tazhong and Guaizihu was 8.0 and $0.5 \%$, respectively. The simulation results did not describe the calm winds well in these regions. Notably, the different frequencies of wind speed and direction between the observational records and numerical model might have contributed to the deviations in the results. Chen 

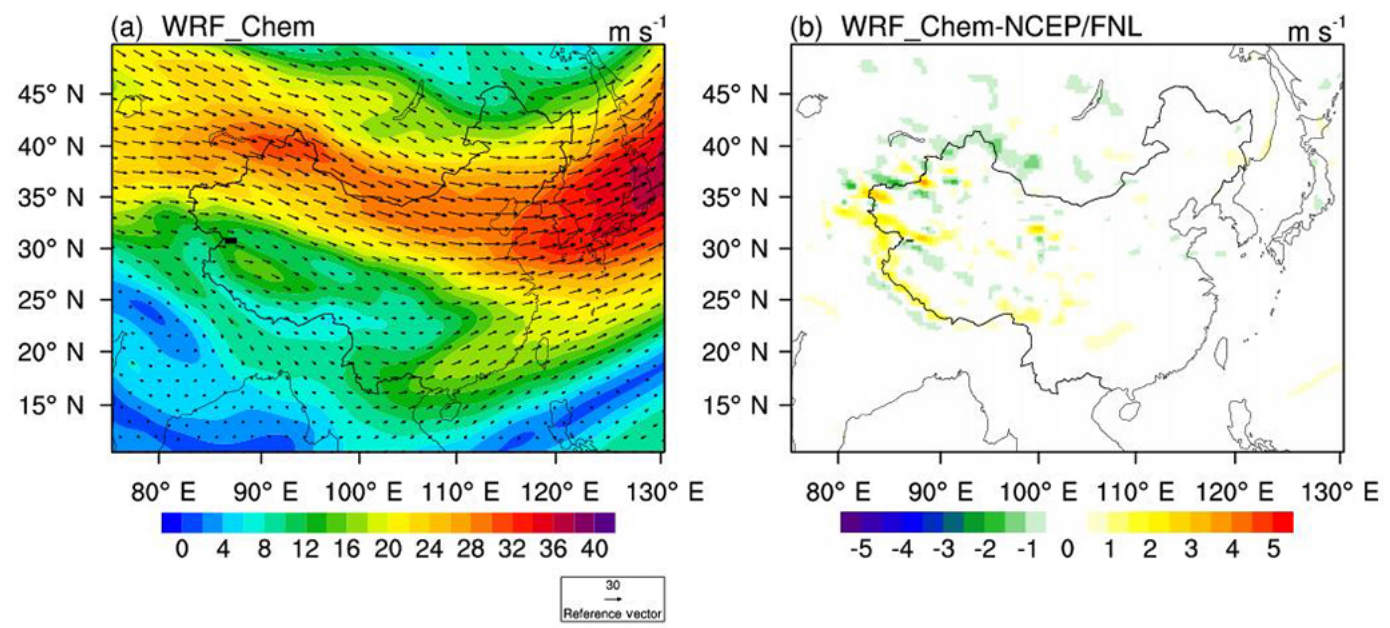

(c) WRF_Chem
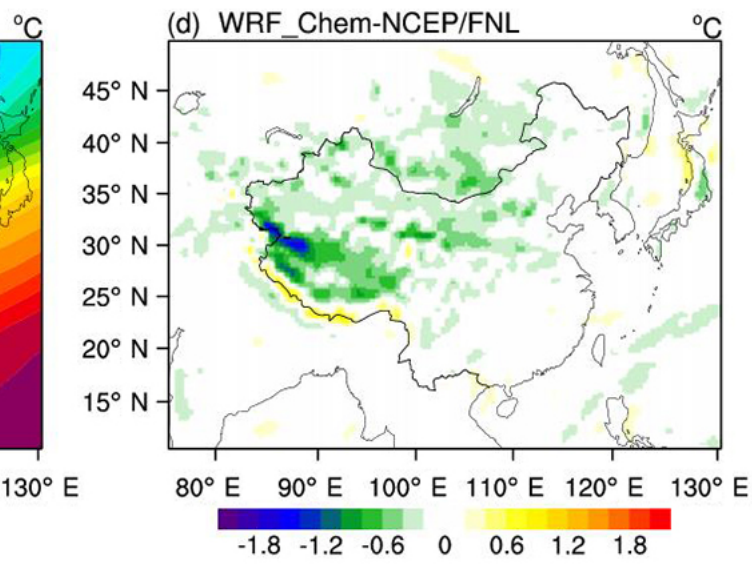

Figure 2. Simulated average wind (a) and temperature (c) fields at $500 \mathrm{hPa}$ and the difference between the simulation and NCEP/FNL reanalysis data (b, d) over East Asia from 18 to 23 March 2010 (hereafter referred to as the simulation period). Arrows represent the wind vector at $500 \mathrm{hPa}$.

et al. (2014a) analyzed the monthly averages of the $10 \mathrm{~m}$ winds over the TD and GD during 2007-2011 from observations, reanalysis data, and WRF-Chem simulations and found that the WRF-Chem model could reproduce the observed seasonal and inter-annual variations in the wind field over the TD and GD. However, the simulations misestimated the observed wind speed because of the limitations of the WRF model in representing sub-grid variations and turbulence processes over complex terrain and land surface types (Hanna et al., 2000). This is a common issue in WRF simulations, which will be improved in a newer version of the WRF model by the addition of surface drag parameterization (Chen et al., 2014a; Jiménez and Dudhia, 2012). Although the simulations overestimated the magnitude of the observed $10 \mathrm{~m}$ wind speed over the TD and GD, they could reproduce the observed spatial distribution of the $10 \mathrm{~m}$ wind speed in dust source regions. Therefore, we could tune the value of the empirical proportionality constant $\mathrm{C}$ in the GOCART dust emission schemes to keep the magnitude of the modeled AOD consistent with the observational data.

\subsection{Spatial and temporal distribution of dust}

The optical properties of the modeled dust were compared with those from surface observation reports and satellite retrievals to validate the WRF-Chem model results. Figure 4 shows the spatial distributions of the daily mean $550 \mathrm{~nm}$ AOD from MODIS and the corresponding WRF-Chem simulations over East Asia. The time series of the observed and modeled AODs at the six AERONET sites (SACOL, Taihu, Mt_WLG, Ussuriysk, Gwangju_GIST, and Shirahama in Fig. 1a and Table 2) are shown in Fig. 5. The vertical profile of dust aerosols is the critical factor that determines the radiative forcing and climate response from mineral dust (Huang et al., 2008). Accurate estimates of the vertical structure are required to reveal variations in dust optical properties and dust long-range transport mechanisms. Cross sections of the aerosol extinction coefficients at $532 \mathrm{~nm}$ over the TD at 20:08 UTC (02:08 LT) on 19 March 2010 from the WRFChem model and CALIPSO retrievals are shown in Fig. 6. 
OBS

WRFCHEM

(a) Tazhong

SpdAve=3 SpdSD=2 DirAve=92 Calm=8.0\% Nwnd=25 SpdAve=5 SpdSD=3 DirAve=82 No Calm Reports Nwnd=144
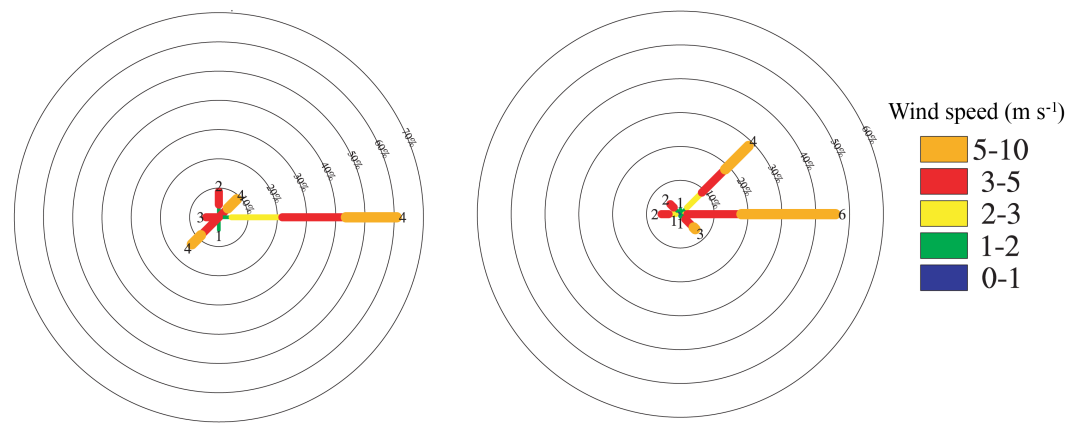

(b) Guaizihu

SpdAve $=6$ SpdSD=4 DirAve $=302 \quad$ Calm=9.5\% Nwnd $=21$

SpdAve $=6$ SpdSD=4 DirAve=286 № Calm Reports Nwnd=144
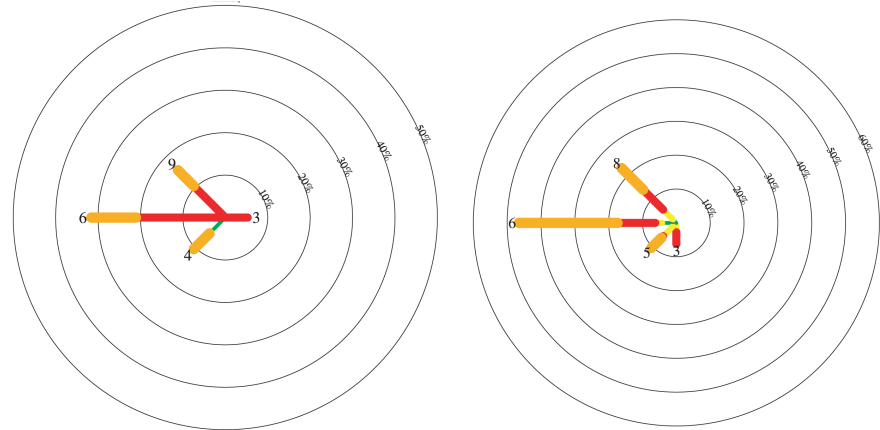

(c) Yumenzhen

SpdAve=4 SpdSD=2 DirAve=71 № Calm Reports Nwnd=25

SpdAve $=6$ SpdSD $=2$ DirAve $=55$ No Calm Reports Nwnd $=144$
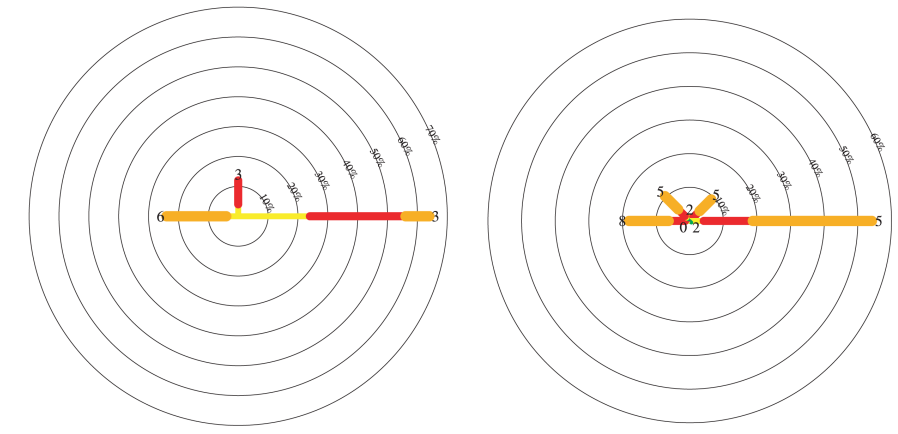

(d) Mazongshan

SpdAve=6 SpdSD=4 DirAve=317 No Calm Reports Nwnd=25 SpdAve=7 SpdSD=3 DirAve=321 No Calm Reports Nwnd=144
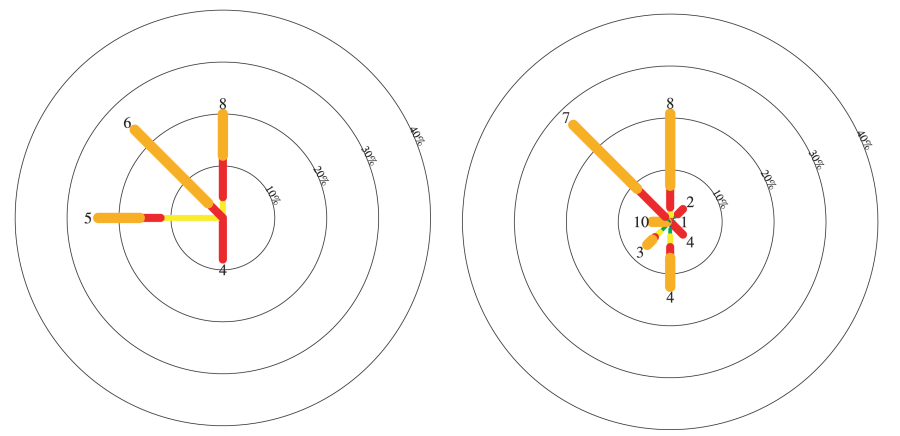

Figure 3. Wind rose diagrams at the four meteorological stations, Tazhong(a), Guaizihu (b), Yumenzhen (c), and Maoyinbadao (d), over the TD and GD during the simulation period from observations and the WRF-Chem model. The mean wind speed is included at the end of each directional line. 


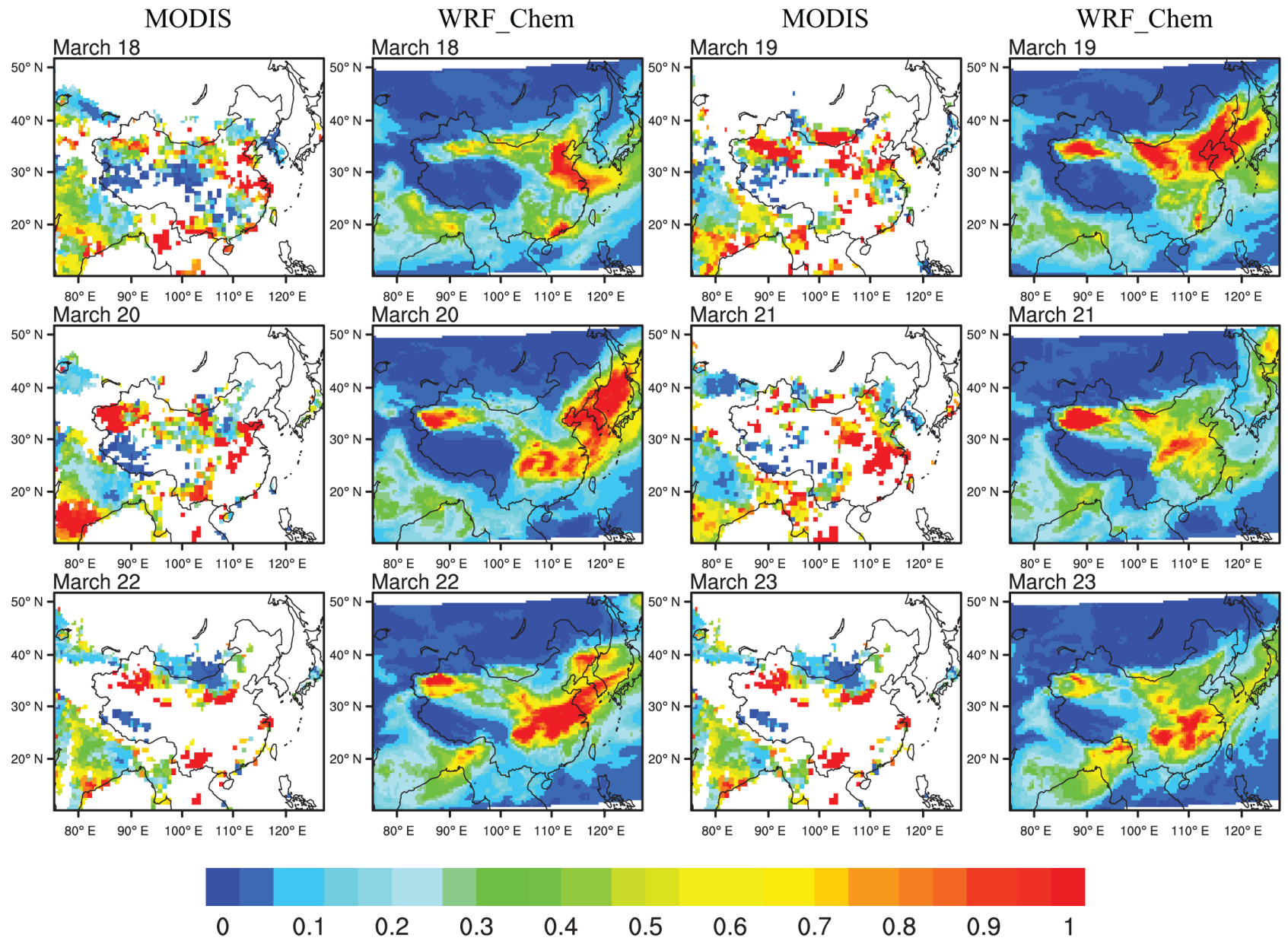

Figure 4. Spatial distributions of the daily mean $550 \mathrm{~nm}$ aerosol optical depths from the MODIS retrievals and the corresponding WRF-Chem simulations over East Asia during the simulation period.

Table 2. Information on selected AERONET stations.

\begin{tabular}{lrrr}
\hline Name & $\begin{array}{r}\text { Latitude } \\
\left({ }^{\circ} \mathrm{N}\right)\end{array}$ & $\begin{array}{r}\text { Longitude } \\
\left({ }^{\circ} \mathrm{E}\right)\end{array}$ & $\begin{array}{r}\text { Elevation } \\
(\mathrm{m})\end{array}$ \\
\hline SACOL (China) & 35.95 & 104.14 & 1965.8 \\
Mt. Waliguan (China) & 36.28 & 100.90 & 3816.0 \\
Taihu (China) & 31.42 & 120.22 & 20.0 \\
Gwangju_GIST (Korea) & 35.23 & 126.84 & 52.0 \\
Shirhuma (Japan) & 33.69 & 135.36 & 10.0 \\
Ussuriysk (Russia) & 43.70 & 132.16 & 280.0 \\
\hline
\end{tabular}

Generally, the MODIS retrievals could be compared to the simulated AOD over East Asia, although the datasets were not insufficient because of their limited spatial and temporal coverage. The simulation results generally captured the observed AODs from the MODIS retrievals over the dust source region, indicating that the GOCART dust emissions represented the dust source function over East Asia well. The average MODIS AOD and simulated AOD over both the TD and
GD were 0.88 and 0.82 , respectively. However, the simulated AOD was lower than the MODIS AOD in the southwestern part of the domain, probably because the anthropogenic emissions in northern India were underestimated in the simulation (Fig. 4).

The peak in dust aerosols occurred over the TD and GD and declined toward the north on 18 March (Fig. 4). The daily average of the observed AOD at SACOL was 0.28, and the corresponding simulated AOD was less than 0.1. Over the remote dust regions, the dust AOD accounted for less than $10 \%$ of the total AOD. Then, a large amount of dust aerosols was injected into the region, especially over the GD on 19 March. The simulated AODs showed good consistency with the AODs determined from the ground-based data (Fig. 4). The dust AOD accounted for more than $95 \%$ of the total AOD at SACOL. The observed AOD was 0.58, which was comparable to the corresponding simulated AOD (0.53) at SACOL.

The observed AOD over the TD exceeded that over the GD by 0.3 on 20 March. The simulated AODs over the GD 


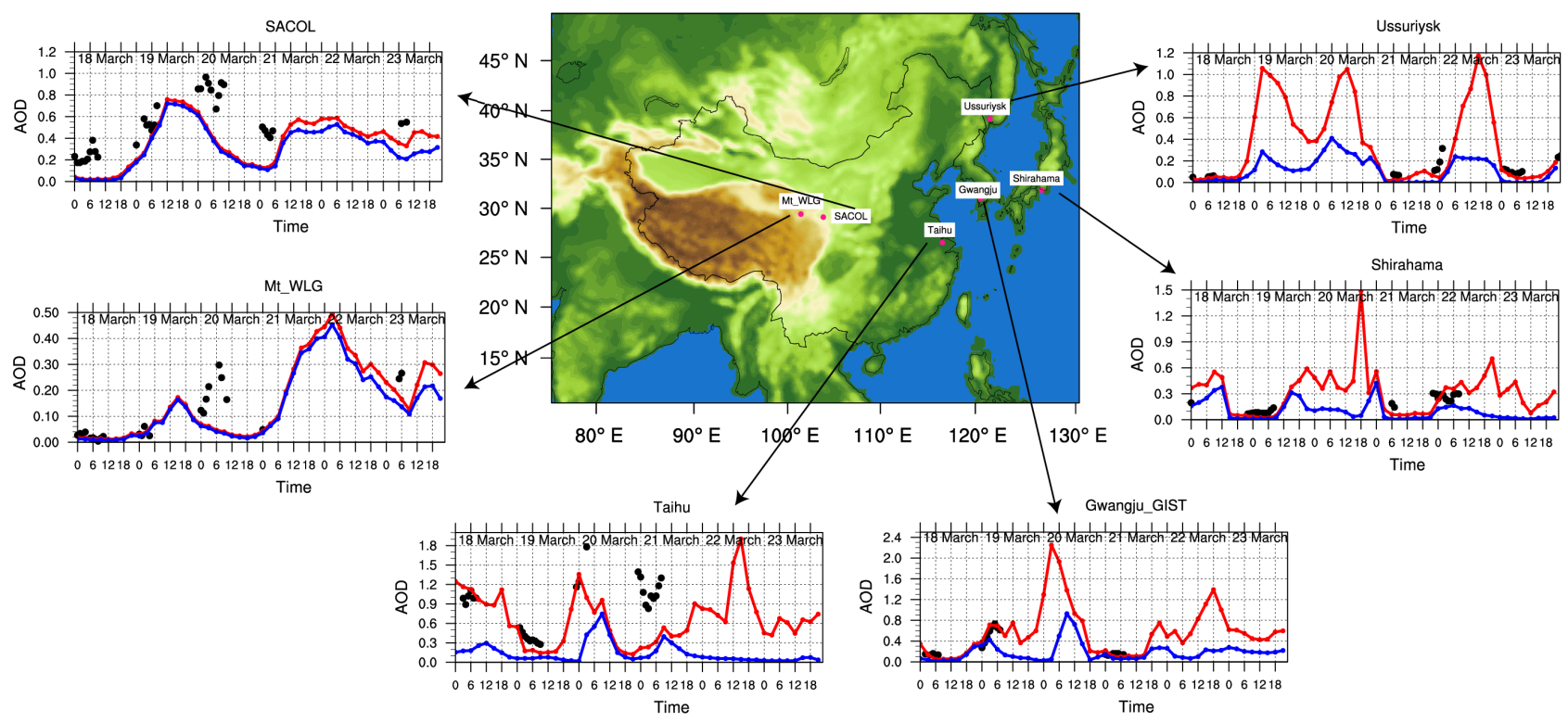

Figure 5. Elevation map in the WRF-Chem domain and time series of the observed and modeled AOD at the six AERONET sites (SACOL, Taihu, Mt. Waliguan (Mt_WLG), Ussuriysk, Gwangju GIST, and Shirahama) during the simulation period. The black dots denote the $1 \mathrm{~h}$ averages of the observed AODs. The red and blue lines represent the modeled total and dust AODs from the WRF-Chem model, respectively.

underestimated the MODIS AODs by up to 0.2 (Fig. 4). The observed AODs at SACOL were higher than the simulated AODs by up to $15 \%$ because of the effects of a local emission source. The AODs at SACOL and Mt. Waliguan AOD showed a decreasing trend. However, the dust AODs began to increase at the Taihu, Ussuriysk, and Gwangju_GIST sites, thus indicating that the dust particles from the dust source regions were being transported to Japan, Korea, and Russia. The Mt. Waliguan AOD increased rapidly to 0.5, and a higher dust AOD $(0.6 \pm 0.14)$ persisted at the Taihu site on 21 March. On 22-23 March, the TD and GD dust mass loadings greatly weakened. The dust AODs were close to 0 , except at the SACOL and Mt. Waliguan sites, which were near the dust source regions (Fig. 5).

Moreover, the WRF-Chem model captured the vertical structure of the aerosols over and near the TD well (Fig. 6). The vertical structure of mineral dust plays an important role in the atmospheric heating rate (Minnis and Cox, 1978; Carlson and Benjamin, 1980), longwave (LW) radiative forcing in clear skies, and shortwave (SW) radiative forcing in cloudy skies (Liao and Seinfeld, 1998; Meloni et al., 2005), thereby directly affecting climate systems through changes in cloud height, cloud life and precipitation because of the changes in the radiative balance. Therefore, accurate estimates of the vertical structure can be reasonably used to reveal variations in dust optical properties and long-range dust transport mechanisms.

\subsection{Dust emission and transport}

The detailed dynamic processes of the strong dust storm event along with the synoptic situation are discussed in this section. The simulation domain was relatively small (Fig. 1a) and the characteristics of the larger-scale changes in atmospheric circulation are not reflected in this discussion. The spatial distributions of the geopotential height, temperature, and wind circulation at 500 and $850 \mathrm{hPa}$ from the NCEP/FNL reanalysis data are shown in Figs. 7 and 8.

The dust storm was initialized by a cold air intrusion in the northern part of Xinjiang on 18 March. The dense isotherm gradient led to stronger cold advection. A mass of cold air accumulated in the northern part of the Tianshan Mountains, which decreased the surface temperatures in northern China. The northwestern flow along the Tianshan Mountains was then injected into the TD (Figs. 7 and 8). The convergence of the warm and cold air masses led to low-level convergence, which created dynamic conditions for the TD dust emission. The GD was located in the warmer zone in advance of the cold front, which generated uplift and further injected dust particles over the GD (Figs. 7 and 8). The dust layer over the GD accumulated at $850 \mathrm{hPa}$. The maximum $\mathrm{PM}_{2.5}$ dust concentration was $41 \mu \mathrm{g} \mathrm{m}^{-3}$ (Fig. 10). The daily average dust emission fluxes over the TD and GD were 20 and $28 \mu \mathrm{g} \mathrm{m}^{-2} \mathrm{~s}^{-1}$, respectively (Fig. 9). This result was consistent with the results of Zhao et al. (2005) and Zhang et al. (2009). Using the Northern Aerosol Regional Climate Model, Zhao et al. (2005) determined that the dust emission over East Asia was approximately $18 \mu \mathrm{g} \mathrm{m}^{-2} \mathrm{~s}^{-1}$ in April and $15 \mu \mathrm{g} \mathrm{m}^{-2} \mathrm{~s}^{-1}$ in May. Zhang et al. (2009) calculated the 

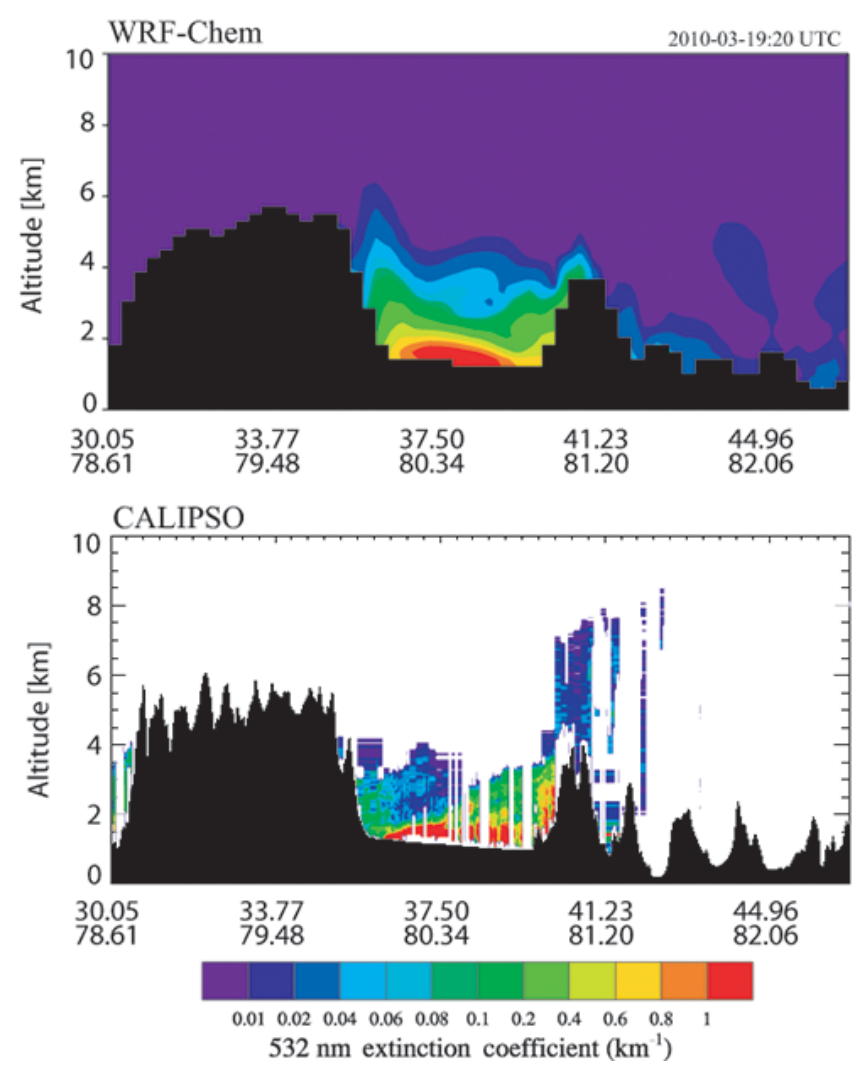

Figure 6. Cross sections of the aerosol extinction coefficients at $532 \mathrm{~nm}\left(\mathrm{~km}^{-1}\right)$ over the TD at 20:08 UTC (02:08 LT) on 19 March 2010 from the WRF-Chem model (top) and CALIPSO retrievals (bottom) along the orbit path of CALIPSO (as shown in Fig. 1a).

dust emission from 1997 to 2006 for the TD along with the surrounding region to be approximately $23 \mu \mathrm{g} \mathrm{m}^{-2} \mathrm{~s}^{-1}$ based on the Regional Climate Model RegCM version 3.

The dust emission over the GD and TD reached a maximum on 19 March for the dust event. The stronger cold advection greatly enhanced the atmospheric baroclinicity because the isotherm was almost perpendicular to the isoheight behind the trough. This context aided the downward transport of momentum produced by the northwestern flow at high levels, which caused the strong winds and dust emissions (Figs. 7 and 8). The $\mathrm{PM}_{2.5}$ dust concentration over the TD reached $65 \mu \mathrm{g} \mathrm{m}^{-3}$ (Fig. 10). The GD dust particles were then transported long distances to eastern and southern China because of the high-level northwestern flow. Thus, the $\mathrm{PM}_{2.5}$ dust concentrations in downwind regions including the Korean Peninsula and Japan increased from 5 to $14 \mu \mathrm{g} \mathrm{m}^{-3}$ at $850 \mathrm{hPa}$. The cold air climbing over the Tianshan Mountains and joining with the strong northeastern cold air over the TD caused a strong northwestern wind, which enhanced the dust emission over the TD. However, the height of the dust layer over the TD (approximately $2 \mathrm{~km}$ ) was lower than that over the GD (approximately $4 \mathrm{~km}$ ) (Fig. 10).
The cold advection behind the trough helped the cold vortex to spread slowly eastward when the angle between the isotherm and isoheight was sufficient on 20 March (Fig. 7). Cold air accumulated to the north of the Tianshan Mountains and then climbed over the mountains, spreading northwestward (Fig. 8). The dust emission over the TD $\left(18.4 \mu \mathrm{g} \mathrm{m}^{-2} \mathrm{~s}^{-1}\right)$ was further enhanced by the influence of the anticyclone behind the cold front. As the upper troughs weakened and moved out, the GD dust emission $\left(8.2 \mu \mathrm{g} \mathrm{m}^{-2} \mathrm{~s}^{-1}\right.$ ) began to decrease (Fig. 9). The $\mathrm{PM}_{2.5}$ dust concentration decreased to $22 \pm 8.2 \mu \mathrm{g} \mathrm{m}^{-3}$ (Fig. 10), thus indicating that the first stage of the dust storm event was essentially complete. The $\mathrm{PM}_{2.5}$ dust concentration in eastern China and the Korean Peninsula continued to increase to a maximum value of $26 \mu \mathrm{g} \mathrm{m}^{-3}$. Dust particles in these downwind regions could reduce the visibility, change the radiative budget, and further modify the atmospheric stability at the regional scale (Chen et al., 2014a; Kang et al., 2013).

The period of 21-23 March is regarded as the second stage of the dust event. The TD dust emission in this stage peaked on 21 March. The average TD dust emission flux was $37.2 \pm 6.4 \mu \mathrm{g} \mathrm{m}^{-2} \mathrm{~s}^{-1}$ (Fig. 9). The frontal zone in the upper atmosphere gradually moved from south to north of $40^{\circ} \mathrm{N}$ (Fig. 7). Cold air climbed over the Pamir Plateau and intruded into the Tarim Basin, which caused strong uplift over the TD. The TD dust particles accompanied by the jet stream and cold advection were transported to most of northern China. However, the strength of the dust emission in this stage was weaker than that on 19 March. The strengthening of the frontal zones gradually decreased, and the descending motions typically occurred over a larger area on 22-23 March (Fig. 8). The dust emission flux decreased to $10 \mu \mathrm{g} \mathrm{m}^{-2} \mathrm{~s}^{-1}$ in the two dust source regions (Fig. 9). Moreover, the prevailing wind was the key factor, producing significant differences in the dust emission and long-range transport over the TD and GD (Fig. 11). The TD is located in a basin surrounded on three sides by mountains. In addition, the wind at the low level over the TD was based on an eastern wind. Therefore, TD dust was not easily transported out of the basin, although the TD had the largest dust emission in the second stage of the dust storm event. Compared to the $\mathrm{TD}$, the GD is relatively flat. In addition, the strong westerly wind over the GD is advantageous for ejecting and further transporting the GD dust. Sun et al. (2001) have also noted that GD dust can be entrained at an elevation of only $<3 \mathrm{~km}$ in most cases (approximately $90 \%$ ). The relatively lower elevation dust layers are deposited mainly in inland China.

From a thermodynamic perspective, the GD dust was also more favorable than the TD dust in terms of the dust emission and vertical transport (Fig. 12). Specifically, the temperature profile over the GD from the surface to $700 \mathrm{hPa}$ was almost parallel to the dry adiabatic rate, indicating that the layer was in an absolutely unstable state, favoring the emission and vertical transport of the GD dust particles. In contrast, the sounding data in the TD revealed an unstable layer near the 

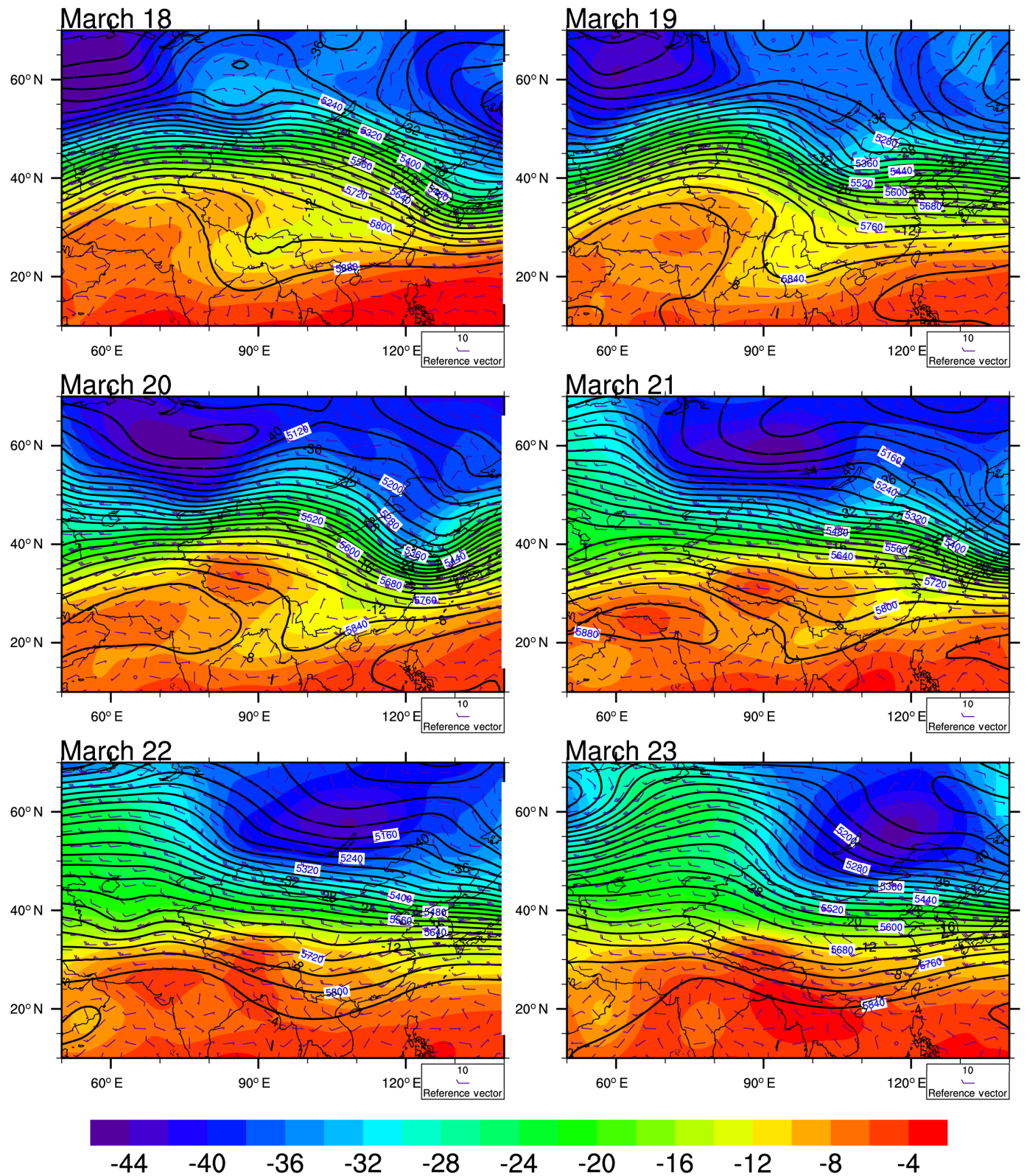

Figure 7. Spatial distributions of the geopotential height (blue lines, unit: gpm) and temperature (color, unit: ${ }^{\circ}$ ) at $500 \mathrm{hPa}$ from the NCEP/FNL reanalysis data over East Asia during the simulation period. The vectors represent the wind field at $500 \mathrm{hPa}\left(\mathrm{m} \times \mathrm{s}^{-1}\right)$.

surface that ranged from the surface to a few hundred meters, helping to vertically elevate the TD dust. Nonetheless, the temperature lapse rate decreased with increasing altitude and was less than the wet adiabatic rate, indicating the existence of an absolutely stable layer and thus requiring more energy to lift an air parcel. Therefore, the vertical movement of the air was inhibited, and the elevation of the dust layer ceased. In addition, the relative humidity in the GD was low within the entire layer, whereas in the TD, the relative humidity remained low in the lower-middle troposphere but increased with height, resulting in a humidity condition that was drier below and wetter above. This condition is the hallmark of a conditionally stable state, which inhibits convective movement in the atmosphere.

\subsection{Dust budget analysis}

To better understand the relative contribution of dust emissions over the TD and GD during the dust storm event, the budgets for the dust emission, transport, and dry and wet deposition were determined over the TD and GD, as shown in Fig. 13. A positive sign represents an increase in dust concentration, and a negative sign represents a decrease in dust 

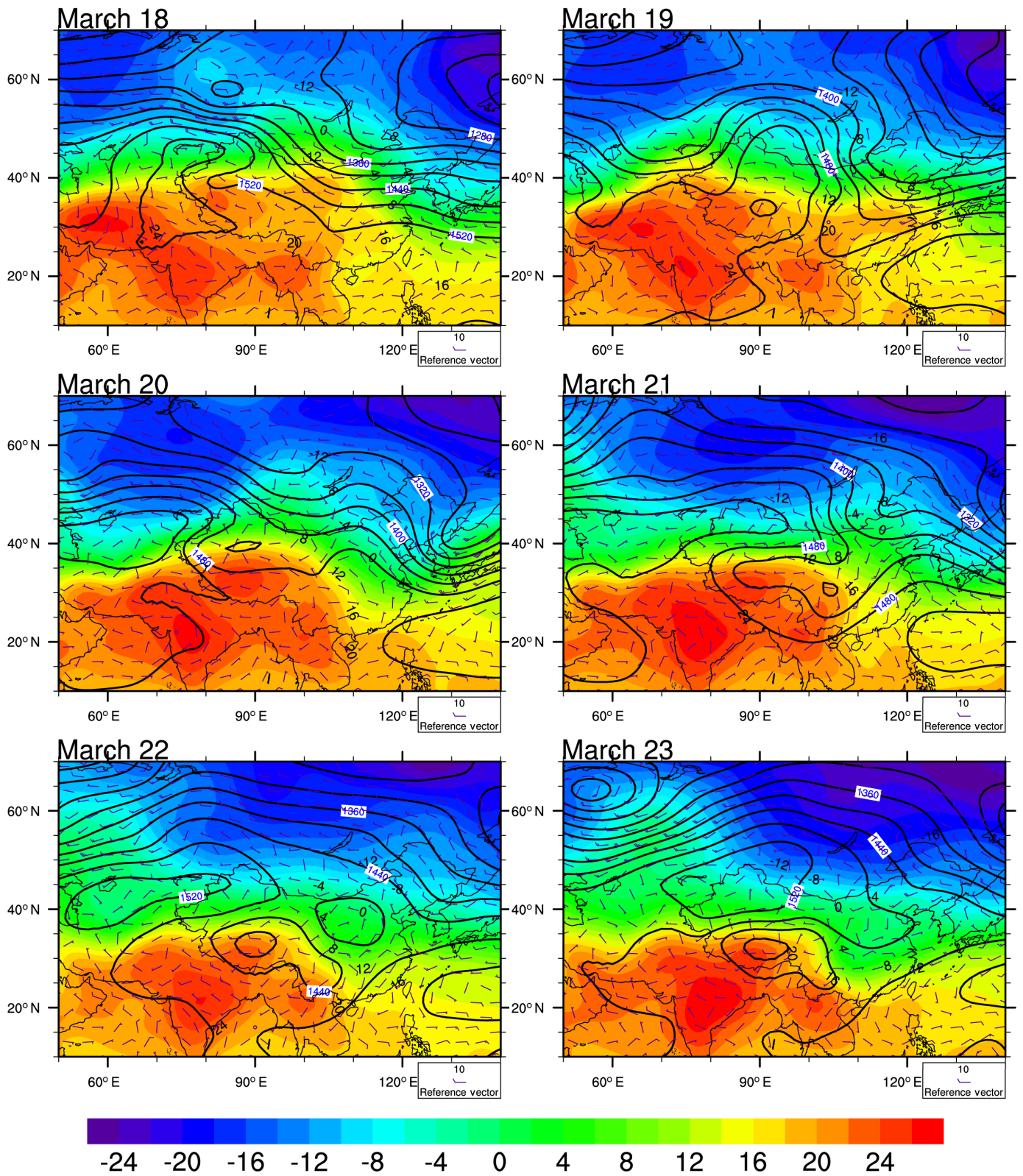

Figure 8. Spatial distributions of the geopotential height (blue lines, unit: gpm) and temperature (color, unit: ${ }^{\circ}$ ) at $850 \mathrm{hPa}$ from the NCEP/FNL reanalysis data over East Asia during the simulation period. The vectors represent the wind field at $850 \mathrm{hPa}\left(\mathrm{m} \times \mathrm{s}^{-1}\right)$.

concentration. Among the four budget terms, the source term of the dust concentration was the absolute dust emission for the entire dust storm event over the TD and GD. The emission contribution was absolutely positive. Dry/wet deposition and transport are sinks for dust in the atmosphere, and their values are always negative. Dry deposition is the largest sink for dust, followed by transport and wet deposition.

Specifically, the GD dust emission was the largest contributor to the dust concentration over East Asia in the first stage (18-20 March) (Fig. 13). The daily dust emission flux over the GD peaked at above $68 \mu \mathrm{g} \mathrm{m}^{-2} \mathrm{~s}^{-1}$ (Fig. 9). The contribution of the transport of the GD dust particles (up to 3.4 ton $^{-1}$ ) was much greater than that of the TD dust particles (up to 1.5 ton $^{-1}$ ) (Fig. 13). Therefore, more GD dust particles could have been transported over East Asia. The strengthening dust emissions weakened substantially in the second stage (21-23 March). The TD dust emission exerted an important effect on the dust concentrations in that stage. The average TD dust emission flux was $20 \pm 4.6 \mu \mathrm{g} \mathrm{m}^{-2} \mathrm{~s}^{-1}$ (Fig. 9). However, the transport capability of the GD dust was still stronger than that of the TD dust in this stage. In Fig. 14, we can observe that the GD dust particles accumulated be- 

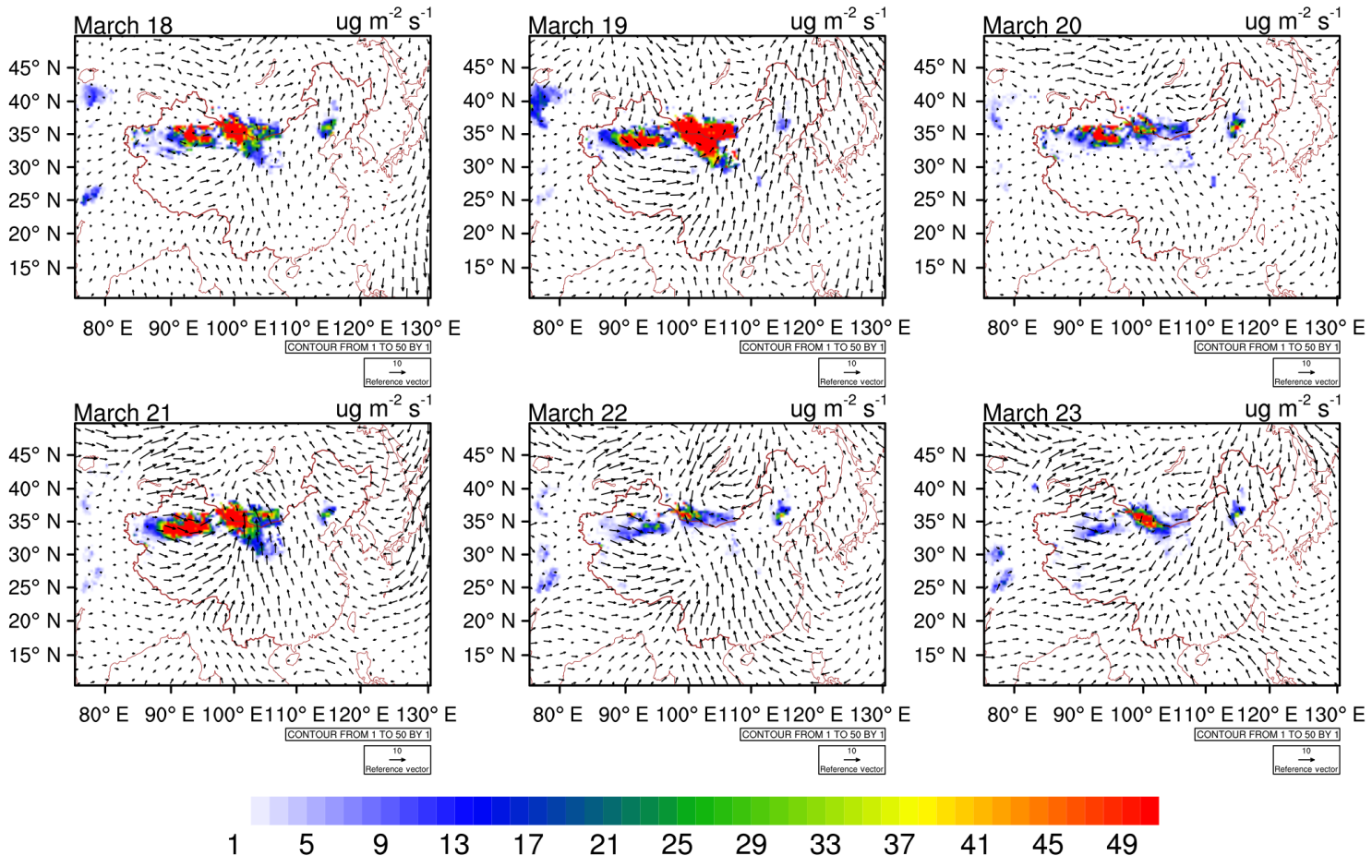

$4145 \quad 49$

Figure 9. Spatial distributions of the daily dust emission $\left(\mu \mathrm{g} \mathrm{m}^{-2} \times \mathrm{s}^{-1}\right)$ over East Asia during the simulation period from WRF-Chem simulations. The arrows represent the wind vectors at $10 \mathrm{~m}\left(\mathrm{~m} \times \mathrm{s}^{-1}\right)$.

low $3 \mathrm{~km}$ between 286 and $296 \mathrm{~K}$. The GD dust concentration reached $1500 \mu \mathrm{g} \mathrm{m}^{-3}$ (Fig. 14). The mass concentrations of the TD dust in the lower-middle troposphere were lower than those of the GD dust.

\subsection{Direct radiative forcing induced by dust over East Asia}

Dust significantly affected the radiation budget over East Asia during the dust storm event. Simulation with and without dust particles was used to estimate the magnitude of dust radiative forcing in this study. The SW, LW, and net $(\mathrm{SW}+\mathrm{LW})$ direct radiative forcing of dust aerosols in allsky conditions were calculated at the top of the atmosphere (TOA), surface (SUR), and in the atmosphere (ATM) during the simulation period, as shown in Fig. 15. The spatial distribution of dust radiative forcing was similar to that of the dust mass loading over East Asia, with the highest values over the TD and GD. The SW forcing induced by dust at the TOA over East Asia was generally negative, with greatest values of -6 to -8 and -2 to $-4 \mathrm{~W} \mathrm{~m}^{-2}$ over the GD and TD, respectively. Compared with the dust aerosols over the Sahara Desert, East Asian dust has a complex refractive index with a small imaginary part, and the back scattering of East Asian dust particles is relatively strong, which led to the high negative values of SW radiation forcing at the TOA (Wang et al., 2004; Jin et al., 2015). The magnitude of the direct radiative forcing at the TOA was dominated by the SW radiative forcing because the LW radiative forcing induced by dust was much smaller $\left(0-1 \mathrm{~W} \mathrm{~m}^{-2}\right)$. The maximum net radiative forcing at the TOA reached $-10 \mathrm{~W} \mathrm{~m}^{-2}$ in southern Inner Mongolia, which was larger than that over the TD $\left(-5 \mathrm{~W} \mathrm{~m}^{-2}\right)$. These data are consistent with the conclusion of Chen et al. (2014a), who found values of -8.3 and $-5.2 \mathrm{~W} \mathrm{~m}^{-2}$ over the GD and TD, respectively.

The SW cooling effect of dust was predominant at the surface, exceeding $-8 \mathrm{~W} \mathrm{~m}^{-2}$ in northern China, which was much stronger than the LW warming effect $(+2$ to $+8 \mathrm{~W} \mathrm{~m}^{-2}$ ). The region of significant $\mathrm{LW}$ radiative forcing occurred mainly over the TD and GD, whereas the higher SW radiative forcing almost covered all of northern China. As a result, the dust caused a strong cooling effect at the surface by weakening the incoming radiation through absorption and scattering by the dust particles (Kumar et al., 2014; Jin et al., 2015). The maximum net radiative forcing at the surface reached $-14 \mathrm{~W} \mathrm{~m}^{-2}$ over the GD and $-9.2 \mathrm{~W} \mathrm{~m}^{-2}$ along the dust transport pathway from northern China to Japan and the Korean Peninsula, which is similar to the conclusions of Zhang et al. (2009). In the atmosphere, the dust aerosols induced positive SW radiative forcing $\left(+1\right.$ to $+11 \mathrm{~W} \mathrm{~m}^{-2}$ ) and negative $\mathrm{LW}$ radiative forcing $\left(-1\right.$ to $\left.-9 \mathrm{~W} \mathrm{~m}^{-2}\right)$, which led to warming in the atmosphere because of dust absorption. The LW radiative forcing was negative over the TD and GD since the dust layers sent the LW radiation to the TOA. The slightly positive net forcing varied from +4 to 

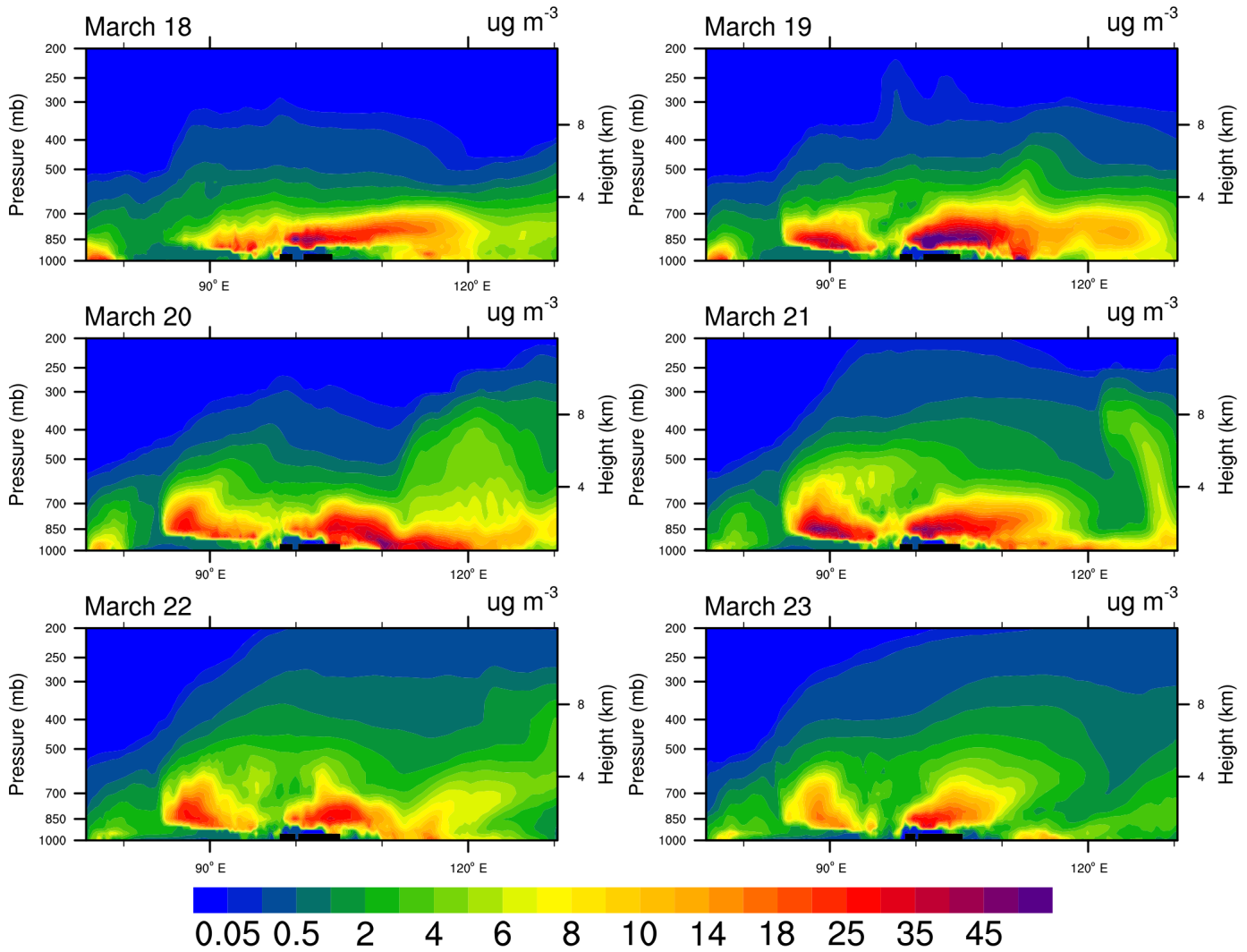

Figure 10. Temporal and spatial cross sections of the meridional mean $\mathrm{PM}_{2.5}$ dust concentration $\left(\mu \mathrm{g} \mathrm{m}^{-3}\right)$ in the domain simulated by the WRF-Chem model during the simulation period.

$+8 \mathrm{~W} \mathrm{~m}^{-2}$ over the TD, +3 to $+6 \mathrm{~W} \mathrm{~m}^{-2}$ over the GD, and 0 to $+4 \mathrm{~W} \mathrm{~m}^{-2}$ over eastern China, which illustrates the warming effect of the dust layers in the atmosphere. The average net dust radiative forcing in the atmosphere varied from +1 to $+6 \mathrm{~W} \mathrm{~m}^{-2}$ over the downwind regions, including eastern China, Korea, and Japan. Therefore, the radiative heating rate of dust has a significant influence on the vertical distribution of temperature in the atmosphere. Fig. 16 further illustrates the vertical profiles of the radiative heating rate induced by dust particles over East Asia. In general, dust induced warming in the atmosphere, especially over the TD and GD. The radiative heating rate reached a maximum of $0.14 \pm 0.03 \mathrm{~K} \mathrm{~d}^{-1}$ over the GD in the $1-3 \mathrm{~km}$ layers, where the dust mass loading was greatest, and gradually decreased with height. In comparison, the radiative heating rate peaked in the 1-2 km layers over the TD at values ranging from 0.04 to $0.12 \mathrm{~K} \mathrm{~d}^{-1}$, lower than those over the GD.

\section{Summary}

The WRF-Chem model was used to investigate a typical dust storm event that occurred from 18 to 23 March 2010 in this study. The WRF-Chem model was capable of simulating East Asian dust during the simulation period. The spa- tial and temporal variations in the large-scale circulation field and dust aerosols over East Asia were captured by the model. These evaluations have provided confidence for further understanding the emission and transport of the TD and GD dust over East Asia based on simulated results. The weather conditions, topography, and surface type of the GD and TD are quite different, which may have led to the difference in dust emission, uplifted height, horizontal and vertical dust flux, and long-range transport. The GD dust contributed significantly to the dust concentration over East Asia, especially on 19 March. The GD was located in the warm zone in advance of a cold front. Rapidly warming surface temperatures and cold air advection at high levels caused strong instability in the atmosphere which strengthened the downward momentum transported from the middle and low troposphere and caused strong surface winds and gusts. The ascending motion and strong surface winds provided the energy needed for dust resuspension, lifting, and transport over the GD. Moreover, the GD is located in a relatively flat and high-altitude region under the influence and confluence of northern and southwesterly winds. Therefore, the GD dust particles were easily lifted to $4 \mathrm{~km}$ and transported eastward over Japan and the Korean Peninsula. The contribution of the transport of the GD dust particles (up to 3.7 ton $\mathrm{d}^{-1}$ ) 

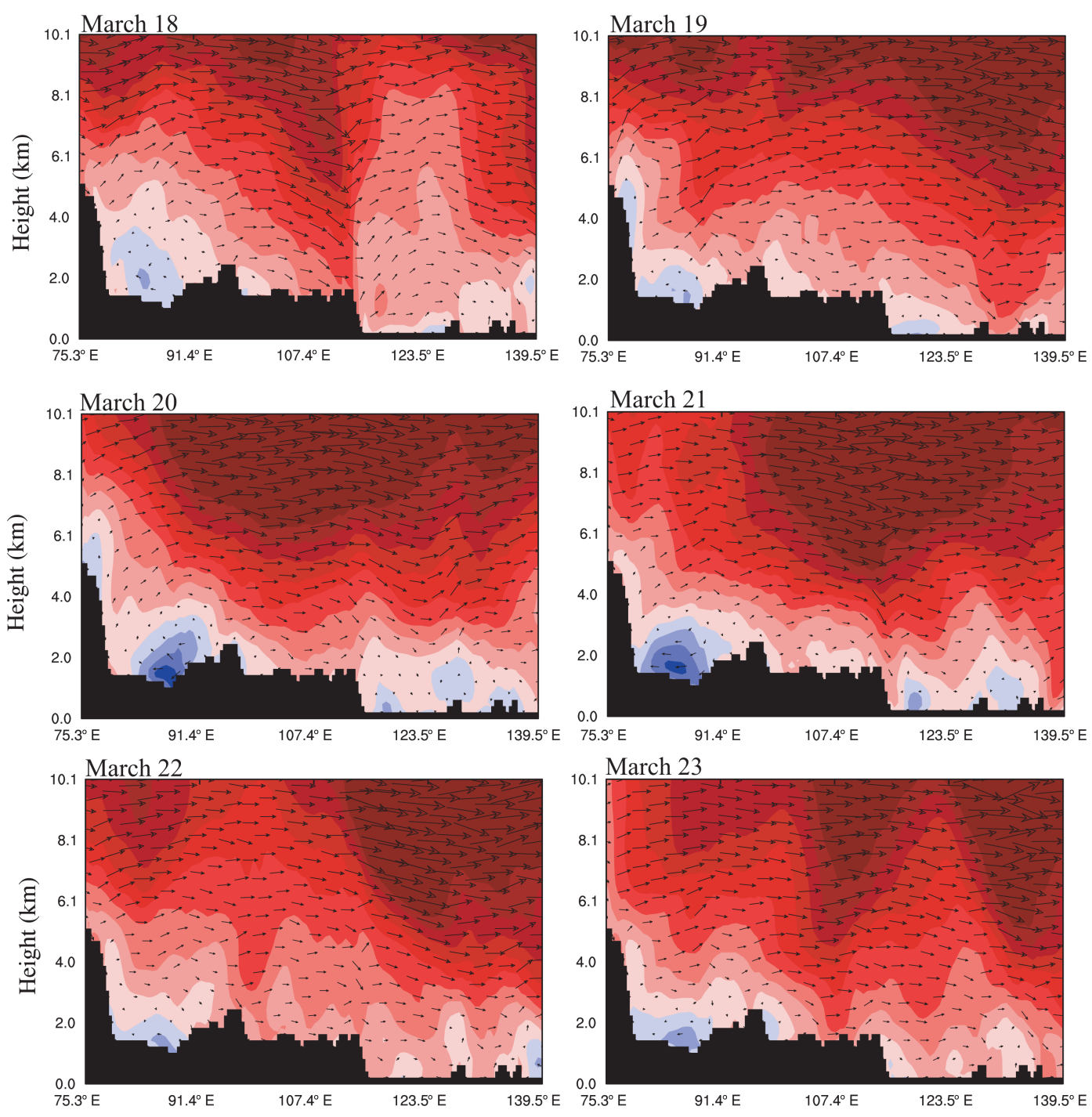

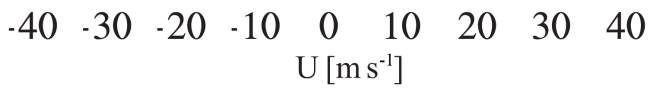

Figure 11. Cross sections of the zonal wind $\left(\mathrm{m} \times \mathrm{s}^{-1}\right)$ and wind vector (vertical wind scaled by $10^{2}$ ) along $42^{\circ} \mathrm{N}$ during the simulation period from the WRF-Chem simulation.

was much greater than that of the TD dust particles (up to 0.8 ton $\mathrm{d}^{-1}$ ) over East Asia during the simulation period.

The TD dust was not easily transported out of the basin because of the complex terrain and prevailing wind, even when the TD had greater dust emissions. Specifically, the TD is surrounded by mountain ranges that exceed $3 \mathrm{~km}$ in height, except for the Hexi Corridor opening to the northeast. The process that generated the dust storms was strongly affected by these topographical characteristics in addition to the surface conditions. Moreover, the easterly wind dominated the TD areas. Thus, the contribution of the transported TD dust to the dust sink was still smaller than that of the GD dust.
However, a small amount of finer dust particles over the TD $\left(\mathrm{PM}_{2.5}\right.$ dust concentration of approximately $\left.8.7 \mu \mathrm{g} \mathrm{m}^{-3}\right)$ was lifted to $4 \mathrm{~km}$ or higher and transported long distances from the source regions. The effects of the TD dust were local and also impacted regions far from the sources.

East Asian dust during the dust storm event played a role in the radiation budget. Generally, compared with previous modeling estimates of direct radiative forcing by dust over East Asia, our estimates were comparable with several modeling studies (Zhang et al., 2009; Han et al., 2012; Chen et al., 2014a; Conant et al., 2003; Park et al., 2005). The net dust radiative forcing over East Asia was approxi- 


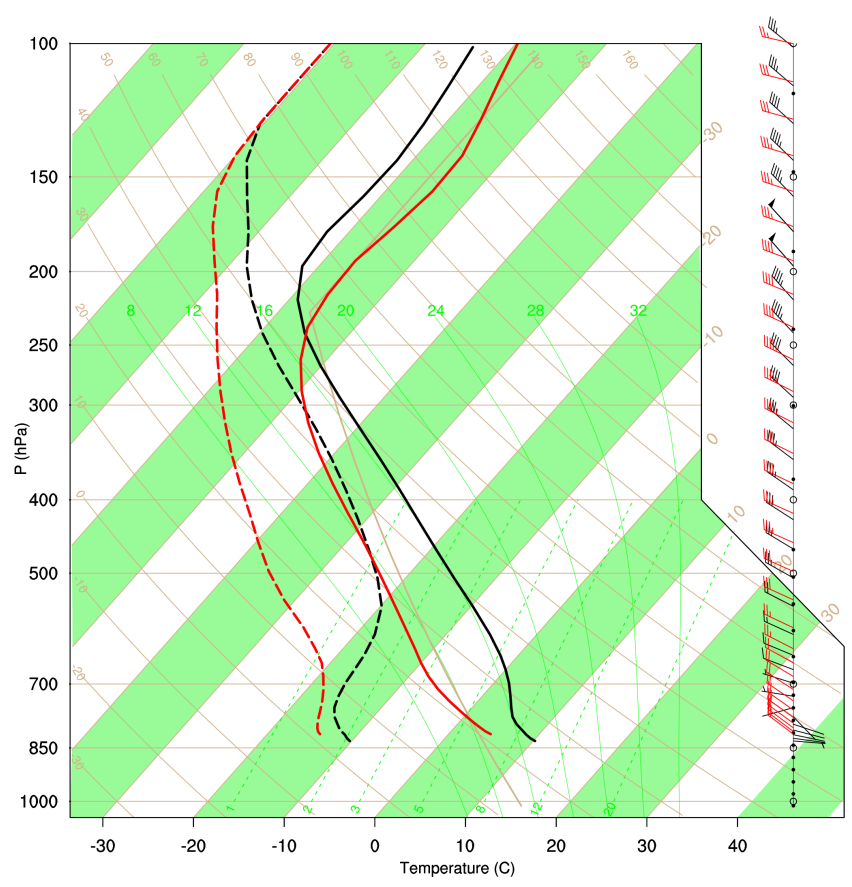

Figure 12. Skew T-log diagram over the TD (black lines) and GD (red lines) on 19 March 2010 from the WRF-Chem simulation. The solid lines represent the temperature, and the dashed lines represent the dew point temperature.

mately $-6.5 \mathrm{~W} \mathrm{~m}^{-2}\left(-8.4 \mathrm{~W} \mathrm{~m}^{-2}\right)$ at the TOA (surface) in this study, which was similar to the estimates given by Conant et al. (2003) and Park et al. (2005) of approximately -5 and $-8 \mathrm{~W} \mathrm{~m}^{-2}\left(-6\right.$ and $\left.-11 \mathrm{~W} \mathrm{~m}^{-2}\right)$ at the TOA (surface), respectively. However, the uncertainties in the direct radiative forcing over East Asia still exist. The biases in the estimates of direct radiative forcing in the simulations could be attributed to the following reasons. First, biases from the dust emission, dust transport, and deposition schemes could greatly affect the assessments of dust radiative forcing in the model. Moreover, differences in the vertical distribution of the dust layer, the dust particle size distribution, the absorptive characteristics, and the meteorological conditions could influence the large differences in the quantitative assessments of dust radiative forcing (Tegen et al., 1996; Wang et al., 2004, 2007; Wu et al., 2004).

Overall, compared with the influence of the TD dust, the importance of the GD dust in the dust concentration in eastern China, Japan, and Korea is most often neglected. Our study focused primarily on the dynamics and thermodynamics of dust emission and transport over the TD and GD and further elucidated the influence of TD and GD dust on the entire East Asian region based on a case study using the WRFChem model. However, the quantitative contributions of TD and GD dust to the dust mass concentrations over East Asia should be further investigated on a longer timescale based on sensitivity tests in a numerical model. In addition, the climate
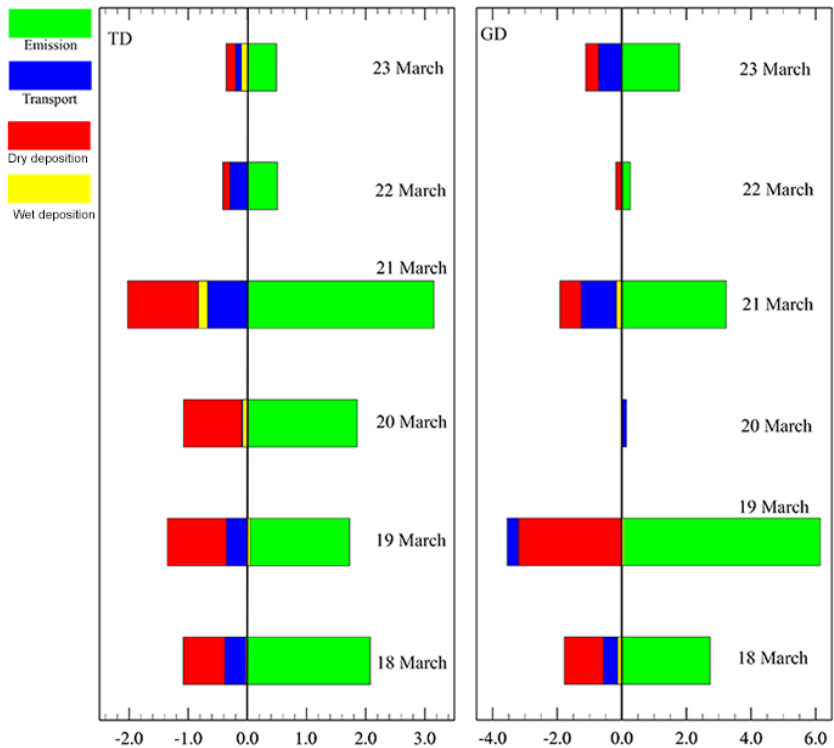

Figure 13. Average contributions of the dust emission, transport, and dry and wet deposition to the dust mass balances over the TD and GD during the simulation period based on the WRF-Chem model. A positive sign represents an increase in dust concentration, and a negative sign represents a decrease in dust concentration. Units: tons $\times \mathrm{d}^{-1}$.

effects of the GD dust over East Asia should be evaluated in the future.

\section{Data availability}

The observation data can be derived from MODIS (https://ladsweb.nascom.nasa.gov/data/search.html),

AERONET (http://aeronet.gsfc.nasa.gov/cgi-bin/ type_piece_of_map_aod_v3) and CALIPSO (https: //eosweb.larc.nasa.gov/project/calipso/calipso_table). 


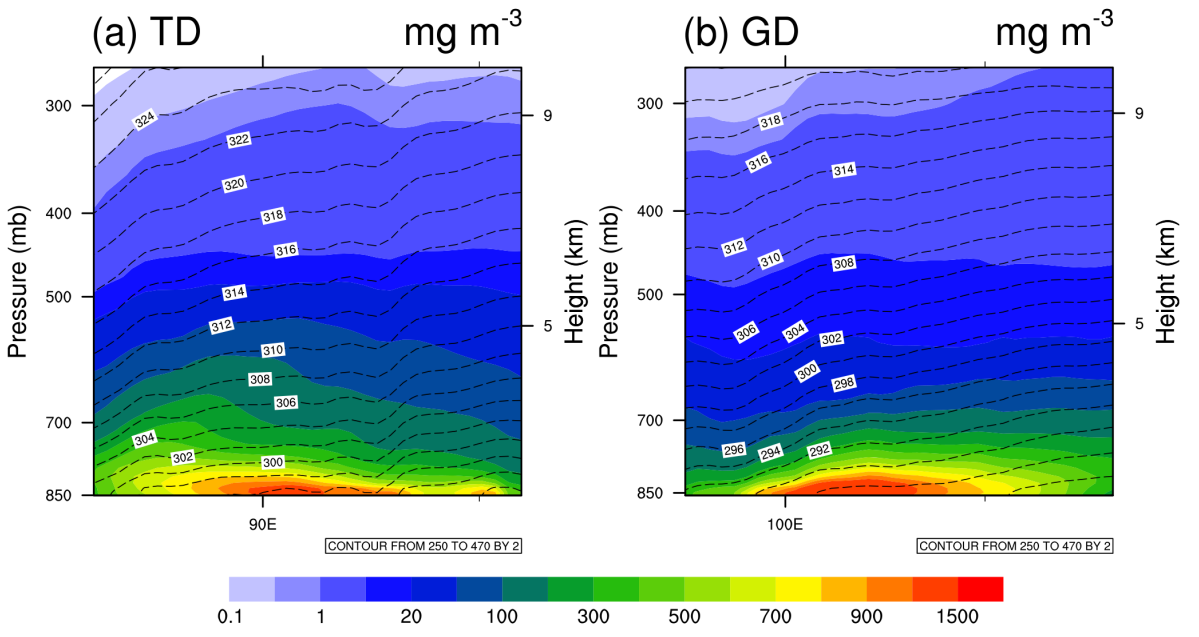

Figure 14. Cross sections of the average dust mass concentrations $\left(\mathrm{mg} \times \mathrm{m}^{-3}\right)$ over the TD (a) and GD (b) during the simulation period based on the WRF-Chem model. The black lines represent the potential temperature (K).
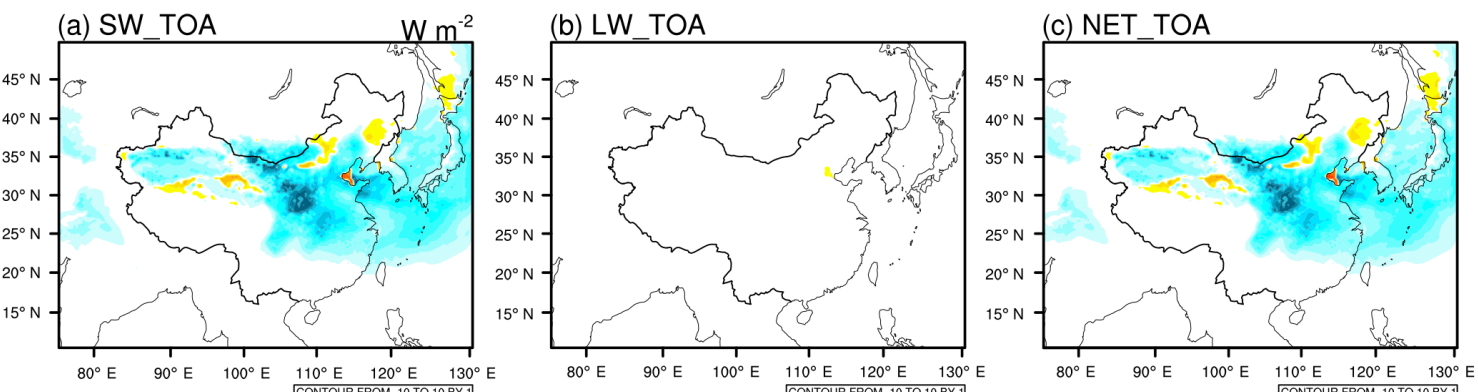

(d) SW_ATM

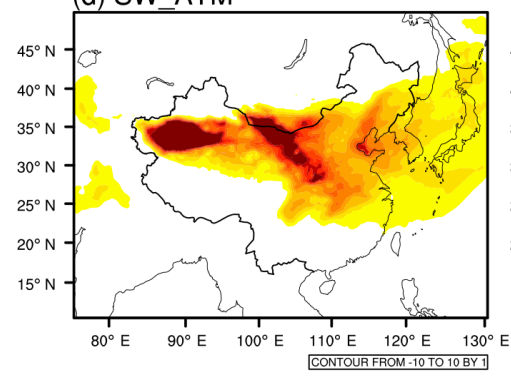

(e) LW_ATM
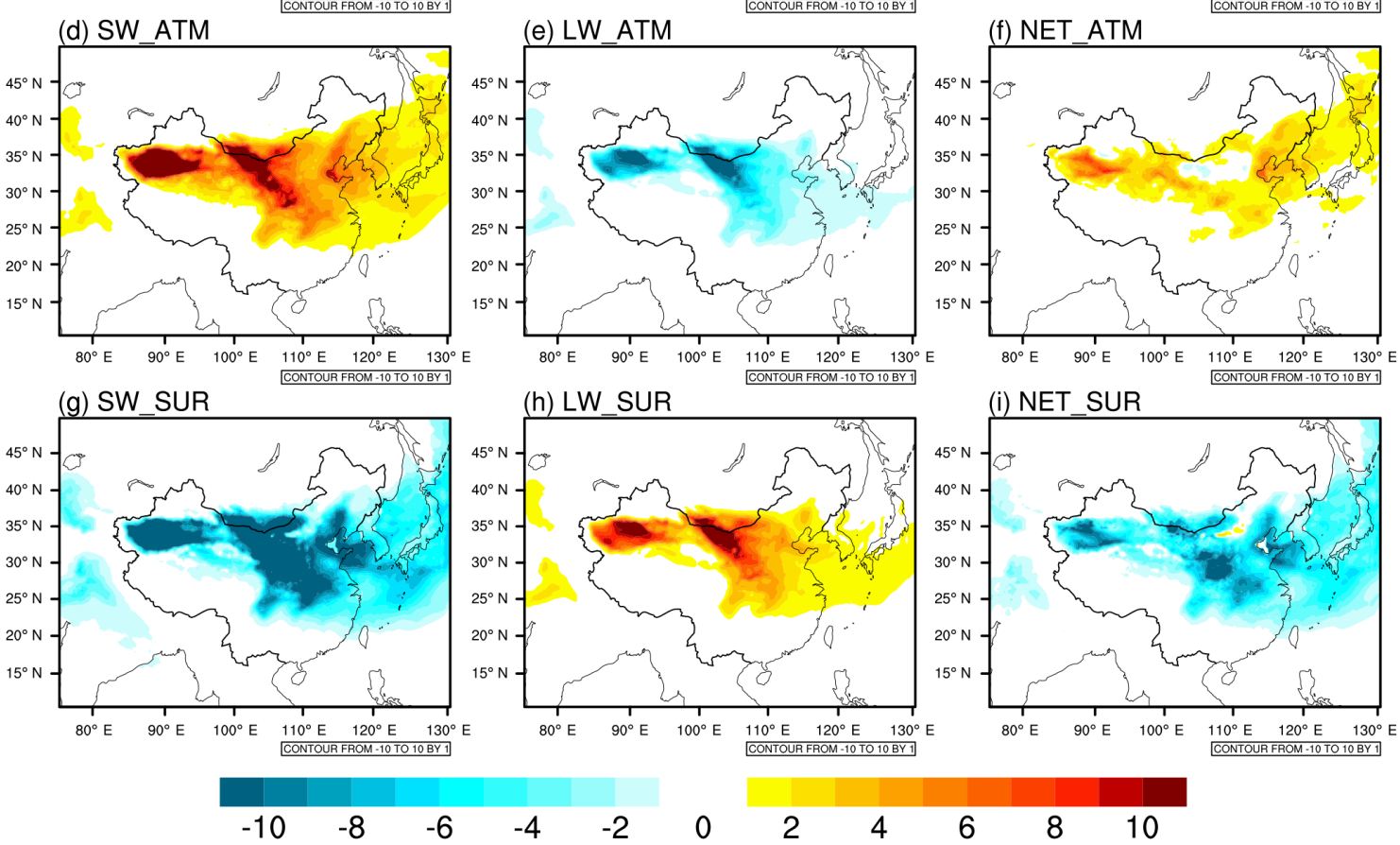

Figure 15. Spatial distributions of the direct radiative forcing by dust for $\mathrm{SW}, \mathrm{LW}$, and net $(\mathrm{SW}+\mathrm{LW})$ radiation $\left(\mathrm{W} \times \mathrm{m}^{-2}\right)$ at the TOA (top panels), SUR (bottom panels), and in the ATM (middle panels) average during the simulation period under all-sky conditions based on the WRF-Chem model. For direct radiative forcing by dust, the positive values represent downward radiative fluxes at the TOA and SUR and represent radiative warming in the ATM. 


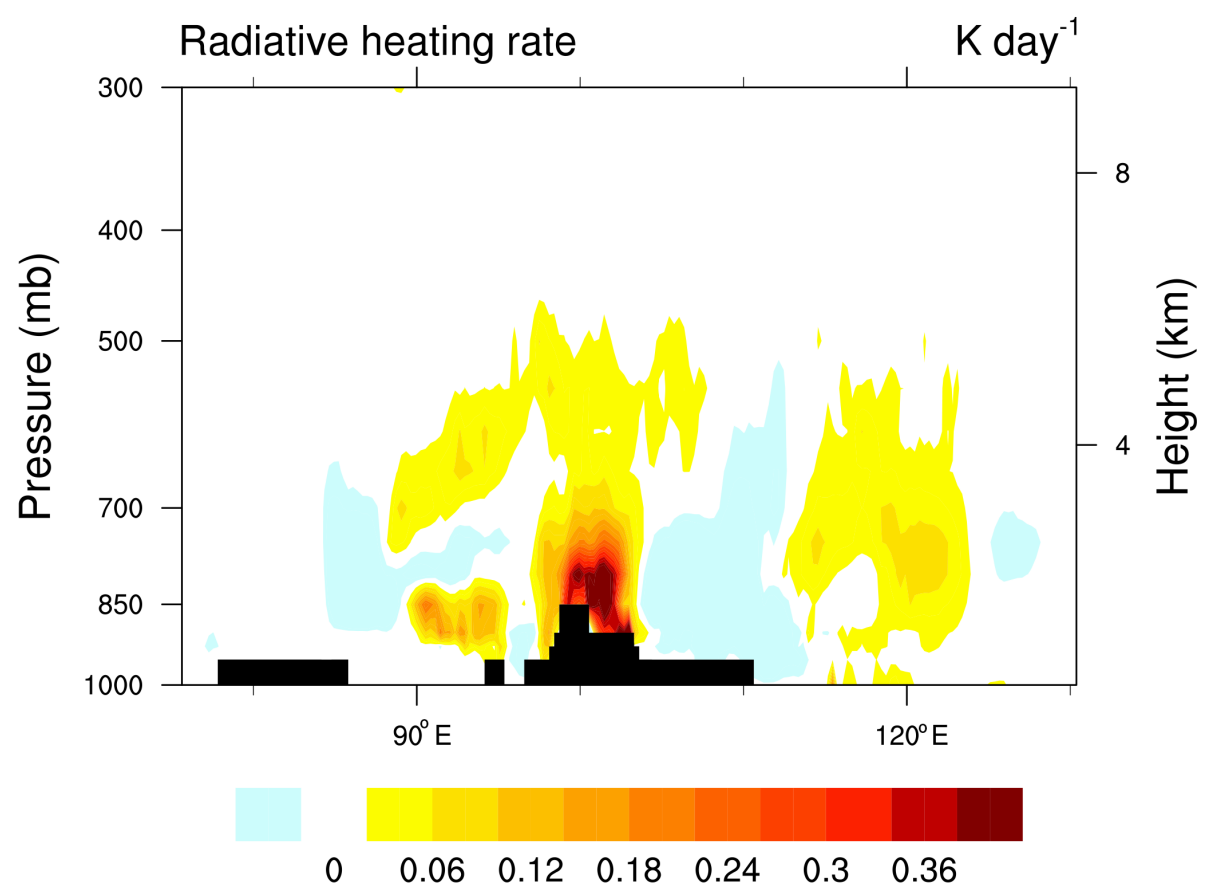

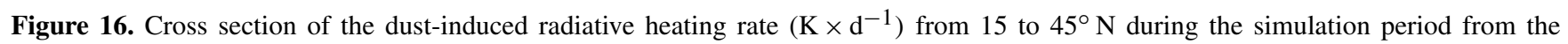
WRF-Chem simulation. 
Competing interests. The authors declare that they have no conflict of interest.

Acknowledgements. We acknowledge Chun Zhao and Yun Qian for their help for this work. This research was supported by the Foundation for Innovative Research Groups of the National Science Foundation of China (grant no. 41521004) and the National Natural Science Foundation of China (no. 41405003).

Edited by: D. Covert

Reviewed by: three anonymous referees

\section{References}

Ackermann, I. J., Hass, H., Memmesheimer, M., Ebel, A., Binkowski, F. S., and Shankar, U.: Modal aerosol dynamics model for Europe, Atmos. Environ., 32, 2981-2999, doi:10.1016/S1352-2310(98)00006-5, 1998.

Barnard, J. C., Fast, J. D., Paredes-Miranda, G., Arnott, W. P., and Laskin, A.: Technical Note: Evaluation of the WRF-Chem "Aerosol Chemical to Aerosol Optical Properties" Module using data from the MILAGRO campaign, Atmos. Chem. Phys., 10, 7325-7340, doi:10.5194/acp-10-7325-2010, 2010.

Bi, J., Huang, J., Fu, Q., Wang, X., Shi, J., Zhang, W., Huang, Z., and Zhang, B.: Toward characterization of the aerosol optical properties over Loess Plateau of Northwestern China, J. Quant. Spectrosc. Ra., 112, 346-360, doi:10.1016/j.jqsrt.2010.09.006, 2011.

Carlson, T. N. and Benjamin, S. G.: Radiative Heating Rates for Saharan Dust, J. Atmos. Sci., 37, 193-213, doi:10.1175/15200469(1980)037<0193:RHRFSD>2.0.CO;2, 1980.

Chen, F. and Dudhia, J.: Coupling an Advanced Land SurfaceHydrology Model with the Penn State-NCAR MM5 Modeling System, Part I: Model Implementation and Sensitivity, Mon. Weather Rev., 129, 569-585, 2001.

Chen, F., Mitchell, K., Schaake, J., Xue, Y., Pan, H. L., Koren, V., Duan, Q. Y., Ek, M., and Betts, A.: Modeling of land surface evaporation by four schemes and comparison with FIFE observations, J. Geophys. Res.-Atmos., 101, 7251-7268, doi:10.1029/95JD02165, 1996.

Chen, S., Huang, J., Zhao, C., Qian, Y., Leung, L. R., and Yang, B.: Modeling the transport and radiative forcing of Taklimakan dust over the Tibetan Plateau: A case study in the summer of 2006, J. Geophys. Res. Atmos., 118, 797-812, doi:10.1002/jgrd.50122, 2013.

Chen, S., Zhao, C., Qian, Y., Leung, Ruby, L., Huang, J., Huang, Z. W., Bi, J. R., Zhang, W., Shi, J., Yang, L., Li, D., and Li, J.: Regional modeling of dust mass balance and radiative forcing over East Asia using WRF-Chem, Aeolian Research, 15, 15-30, doi:10.1016/j.aeolia.2014.02.001, 2014a.

Chen, S., Huang, J., Qian, Y., Ge, J., and Su, J.: Effects of aerosols on autumn precipitation over Mid-Eastern China, J. Trop. Meteorol., 20, 242-250, 2014b.

Dubovik, O. and King, M. D.: A flexible inversion algorithm for retrieval of aerosol optical properties from Sun and sky radiance measurements, J. Geophys. Res. Atmos., 105, 20673-20696, doi:10.1029/2000JD900282, 2000.
Dubovik, O., Holben, B., Eck, T. F., Smirnov, A., Kaufman, Y. J., King, M. D., Tanré, D., and Slutsker, I.: Variability of Absorption and Optical Properties of Key Aerosol Types Observed in Worldwide Locations, J. Atmos. Sci., 59, 590-608, doi:10.1175/15200469(2002)059<0590:VOAAOP>2.0.CO;2, 2002.

Eguchi, K., Uno, I., Yumimoto, K., Takemura, T., Shimizu, A., Sugimoto, N., and Liu, Z.: Trans-pacific dust transport: integrated analysis of NASA/CALIPSO and a global aerosol transport model, Atmos. Chem. Phys., 9, 3137-3145, doi:10.5194/acp-93137-2009, 2009.

Fu, Q., Thorsen, T. J., Su, J., Ge, J., and Huang, J.: Test of Miebased single-scattering properties of non-spherical dust aerosols in radiative flux calculations, J. Quant. Spectros. Ra., 110, 1640 1653, doi:10.1016/j.jqsrt.2009.03.010, 2009.

Ge, J. J., Huang, C., Xu, Y., Qi, and H., Liu: Characteristics of Taklimakan dust emission and distribution: A satellite and reanalysis field perspective, J. Geophys. Res.-Atmos., 119, 11772-11783, doi:10.1002/2014JD022280, 2014.

Ginoux, P., Chin, M., Tegen, I., Prospero, J. M., Holben, B., Dubovik, O., and Lin, S. J.: Sources and distributions of dust aerosols simulated with the GOCART model, J. Geophys. Res., 106, 20255, doi:10.1029/2000JD000053, 2001.

Grell, G. A., Peckham, S. E., Schmitz, R., McKeen, S. A., Frost, G., Skamarock, W. C., and Eder, B.: Fully coupled "online" chemistry within the WRF model, Atmos. Environ., 39, 6957-6975, doi:10.1016/j.atmosenv.2005.04.027, 2005.

Han, Z., Li, J., Xia, X., and Zhang, R.: Investigation of direct radiative effects of aerosols in dust storm season over East Asia with an online coupled regional climatechemistry-aerosol model, Atmos. Environ., 54, 688-699, doi:10.1016/j.atmosenv.2012.01.041, 2012.

Hanna, S. R., Yang, R., and Yin, X.: Evaluations of numerical weather prediction (NWP) models from the point of view of inputs required by atmospheric dispersion models, Int. J. Environ. Pollut., 14, 98-105, doi:10.1504/IJEP.2000.000530, 2000.

Hong, S. Y., Noh, Y., and Dudhia, J.: A New Vertical Diffusion Package with an Explicit Treatment of Entrainment Processes, Mon. Weather Rev., 134, 2318-2341, doi:10.1175/MWR3199.1, 2006.

Hsu, N. C., Tsay, S. C., King, M. D., and Herman, J. R.: Deep Blue Retrievals of Asian Aerosol Properties during ACEAsia, IEEE Trans. Geosci. Remote Sens., 44, 3180-3195, doi:10.1109/TGRS.2006.879540, 2006.

Huang, J., Lin, B., Minnis, P., Wang, T., Wang, X., Hu, Y., Yi, Y., and Ayers, J. K.: Satellite-based assessment of possible dust aerosols semi-direct effect on cloud water path over East Asia, Geophys. Res. Lett., 33, L19802, doi:10.1029/2006GL026561, 2006a.

Huang, J., Wang, Y., Wang, T., and Yi, Y.: Dusty cloud radiative forcing derived from satellite data for middle latitude regions of East Asia, Prog. Nat. Sci., 16, 1084-1089, doi:10.1080/10020070612330114, 2006b.

Huang, J., Minnis, P., Lin, B., Wang, T., Yi, Y., Hu, Y., SunMack, S., and Ayers, K.: Possible influences of Asian dust aerosols on cloud properties and radiative forcing observed from MODIS and CERES, Geophys. Res. Lett., 33, L06824, doi:10.1029/2005GL024724, 2006c.

Huang, J., Minnis, P., Yi, Y., Tang, Q., Wang, X., Hu, Y., Liu, Z., Ayers, K., Trepte, C., and Winker, D.: Summer dust aerosols de- 
tected from CALIPSO over the Tibetan Plateau, Geophys. Res. Lett., 34, L18805, doi:10.1029/2007GL029938, 2007.

Huang, J. P., Huang, Z. W., Bi, J. R., Zhang, W., and Zhang, L.: Micro-pulse lidar measurements of aerosol vertical structure over the Loess Plateau, Atmos. Ocean. Sci. Lett., 1, 8-11, doi:10.1080/16742834.2008.11446756, 2008a.

Huang, J. P., Minnis, P., Chen, B., Huang, Z., Liu, Z., Zhao, Q., Yi, Y., and Ayers, J. K.: Long-range transport and vertical structure of Asian dust from CALIPSO and surface measurements during PACDEX, J. Geophys. Res., 113, D23212, doi:10.1029/2008JD010620, 2008b.

Huang, J. P., Zhang, W., Zuo, J., Bi, J., Shi, J., Wang, X., Chang, Z., Huang, Z., Yang, S., Zhang, B., Wang, G., Feng, G., Yuan, J., Zhang, L., Zuo, H., Wang, S., Fu, C., and Jifan, C.: An overview of the Semi-arid Climate and Environment Research Observatory over the Loess Plateau, Adv. Atmos. Sci., 25, 906-921, doi:10.1007/s00376-008-0906-7, 2008c.

Huang, J. P., Fu, Q., Su, J., Tang, Q., Minnis, P., Hu, Y., Yi, Y., and Zhao, Q.: Taklimakan dust aerosol radiative heating derived from CALIPSO observations using the Fu-Liou radiation model with CERES constraints, Atmos. Chem. Phys., 9, 4011-4021, doi:10.5194/acp-9-4011-2009, 2009.

Huang, J. P., Minnis, P., Yan, H., Yi, Y., Chen, B., Zhang, L., and Ayers, J. K.: Dust aerosol effect on semi-arid climate over Northwest China detected from A-Train satellite measurements, Atmos. Chem. Phys., 10, 6863-6872, doi:10.5194/acp-10-68632010, 2010

Huang, J. P., Fu, Q., Zhang, W., Wang, X., Zhang, R., Ye, H., and Warren, S. G.: Dust and Black Carbon in Seasonal Snow Across Northern China, Bull. Am. Meteorol. Soc., 92, 175-181, doi:10.1175/2010BAMS3064.1, 2011.

Huang, J. P., Guan, X., and Ji, F.: Enhanced cold-season warming in semi-arid regions, Atmos. Chem. Phys., 12, 5391-5398, doi:10.5194/acp-12-5391-2012, 2012.

Huang, J. P., Wang, T., Wang, W., Li, Z., and Yan, H.: Climate effects of dust aerosols over East Asian arid and semiarid regions, J. Geophys. Res.-Atmos., 119, 11398-11416, doi:10.1002/2014JD021796, 2014.

Huang, J. P., Yu, H., Guan, X., Wang, G., and Guo, R.: Accelerated dryland expansion under climate change, Nature Climate Change, 6, 166-171, doi:10.1038/nclimate2837, 2016.

Huang, X. X., Wang, T. J., Jiang, F., Liao, J. B., Cai, Y. F., Yin, C. Q., Zhu, J. L., and Han, Y.: Studies on a severe dust storm in East Asia and its impact on the air quality of Nanjing, China, Aerosol Air Qual. Res., 13, 179-193, doi:10.4209/aaqr.2012.05.0108, 2013.

Huang, Z., Huang, J., Bi, J., Wang, G., Wang, W., Fu, Q., Li, Z., Tsay, S., and Shi, J.: Dust aerosol vertical structure measurements using three MPL lidars during 2008 China-US joint dust field experiment, J. Geophys. Res.-Atmos., 115, 1307-1314, doi:10.1029/2009JD013273, 2010.

Jiménez, P. A. and Dudhia, J.: Improving the Representation of Resolved and Unresolved Topographic Effects on Surface Wind in the WRF Model, J. Appl. Meteorol. Climatol., 51, 300-316, doi:10.1175/JAMC-D-11-084.1, 2012.

Jin, Q., Wei, J., Yang, Z.-L., Pu, B., and Huang, J.: Consistent response of Indian summer monsoon to Middle East dust in observations and simulations, Atmos. Chem. Phys., 15, 9897-9915, doi:10.5194/acp-15-9897-2015, 2015.
Kain, J. S.: The Kain-Fritsch Convective Parameterization: An Update, J. Appl. Meteorol., 43, 170-181, doi:10.1175/15200450(2004)043<0170:TKCPAU>2.0.CO;2, 2004.

Kain, J. S. and Fritsch, J. M.: A One-Dimensional Entraining/Detraining Plume Model and Its Application in Convective Parameterization, J. Atmos. Sci., 47, 2784-2802, doi:10.1175/1520-0469(1990)047<2784:AODEPM>2.0.CO;2, 1990.

Kaufman, Y. J., Wald, A. E., Remer, L. A., Gao, B. C., Li, R. R., and Flynn, L.: The MODIS 2.1-mm channel-correlation with visible reflectance for use in remote sensing of aerosol, IEEE Trans. Geosci. Remote Sens., 35, 1286-1298, doi:10.1109/36.628795, 1997.

Koren, I., Kaufman, Y. J., Remer, L. A., and Martins, J. V.: Measurement of the effect of Amazon smoke on inhibition of cloud formation, Science, 303, 1342-1345, doi:10.1126/science.1089424, 2004.

Kurosaki, Y. and Mikami, M.: Threshold wind speed for dust emission in East Asia and its seasonal variations, J. Geophys. Res., 112, D17202, doi:10.1029/2006JD007988, 2007.

Li, J., Wang, Z., Zhuang, G., Luo, G., Sun, Y., and Wang, Q.: Mixing of Asian mineral dust with anthropogenic pollutants over East Asia: a model case study of a super-dust storm in March 2010, Atmos. Chem. Phys., 12, 7591-7607, doi:10.5194/acp-127591-2012, 2012.

Li, Z., Li, C., Chen, H., Tsay, S. C., Holben, B., Huang, J., Li, B., Maring, H., Qian, Y., Shi, G., Xia, X., Yin, Y., Zheng, Y., and Zhuang, G.: East Asian Studies of Tropospheric Aerosols and their Impact on Regional Climate (EAST-AIRC): An overview, J. Geophys. Res., 116, D00K34, doi:10.1029/2010JD015257, 2011.

Liao, H. and Seinfeld, J. H.: Radiative forcing by mineral dust aerosols: Sensitivity to key variables, J. Geophys. Res.-Atmos., 103, 31637-31645, doi:10.1029/1998JD200036, 1998.

Liu, Z., Vaughan, M. A., Winker, D. M., Hostetler, C. A., Poole, L. R., Hlavka, D., Hart, W., and McGill, M.: Use of probability distribution functions for discriminating between clouds and aerosol in lidar backscatter data, J. Geophys. Res.-Atmos., 109, 1255-1263, doi:10.1029/2004JD004732, 2004

Martonchik, J. V., Diner, D. J., Crean, K., and Bull, M.: Regional aerosol retrieval results from MISR, IEEE Trans. Geosci. Remote Sens., 40, 1520-1531, 2002.

Martonchik, J. V., Diner, D. J., Kahn, R. A., Gaitley, B. J., and Holben, B. N.: Comparison of MISR and AERONET aerosol optical depths over desert sites, Geophys. Res. Lett., 31, L16102, doi:10.1029/2004GL019807, 2004.

Meloni, D., di Sarra, A., Di Iorio, T., and Fiocco, G.: Influence of the vertical profile of Saharan dust on the visible direct radiative forcing, J. Quant. Spectrosc. Ra., 93, 397-413, doi:10.1016/j.jqsrt.2004.08.035, 2005.

Minnis, P. and Cox, S. K.: Magnitude of the radiative effects of the Sahara dust layer, Atmos. Sci., 111-283, 1978.

Morrison, H., Curry, J. A., and Khvorostyanov, V. I.: A New Double-Moment Microphysics Parameterization for Application in Cloud and Climate Models, Part I: Description, J. Atmos. Sci., 62, 1665-1677, doi:10.1175/JAS3446.1, 2005.

Qian, Y., Gong, D., Fan, J., Leung, L. R., Bennartz, R., Chen, D., and Wang, W.: Heavy pollution suppresses light rain in China: 
Observations and modeling, J. Geophys. Res., 114, D00K02, doi:10.1029/2008JD011575, 2009.

Ramanathan, V., Crutzen, P. J., Kiehl, J. T., and Rosenfeld, D.: Aerosols, climate, and the hydrological cycle, Science, 294, 2119-2124, doi:10.1126/science.1064034, 2001.

Rea, D. K.: The paleoclimatic record provided by eolian deposition in the deep sea: The geologic history of wind, Rev. Geophys., 32, 159-195, doi:10.1029/93RG03257, 1994.

Schell, B., Ackermann, I. J., Hass, H., Binkowski, F. S., and Ebel, A.: Modeling the formation of secondary organic aerosol within a comprehensive air quality model system, J. Geophys. Res.Atmos., 106, 28275-28293, doi:10.1029/2001JD000384, 2001.

Shao, Y., Ishizuka, M., Mikami, M., and Leys, J. F.: Parameterization of size-resolved dust emission and validation with measurements, J. Geophys. Res., 116, D08203, doi:10.1029/2010JD014527, 2011.

Skamarock, W. C., Klemp, J. B., Dudhia, J., Gill, D. O., Baker, D. M., Duda, M. G., Huang, X., Wang, W., and Powers, J. G.: A description of the Advanced Research WRF version 3: Mesoscale and Microscale Meteorology Division, National Center for Atmospheric Research, Boulder, Colorado, USA, 88, 7-25, 2008.

Stauffer, D. R. and Seaman, N. L.: Use of Four-Dimensional Data Assimilation in a Limited-Area Mesoscale Model, Part I: Experiments with Synoptic-Scale Data, Mon. Weather Rev., 118, 1250-1277, doi:10.1175/15200493(1990)118<1250:UOFDDA>2.0.CO;2, 1990.

Su, J., Huang, J., Fu, Q., Minnis, P., Ge, J., and Bi, J.: Estimation of Asian dust aerosol effect on cloud radiation forcing using $\mathrm{Fu}-$ Liou radiative model and CERES measurements, Atmos. Chem. Phys., 8, 2763-2771, doi:10.5194/acp-8-2763-2008, 2008.

Sun, J., Zhang, M., and Liu, T.: Spatial and temporal characteristics of dust storms in China and its surrounding regions, 1960-1999: Relations to source area and climate, J. Geophys. Res.-Atmos., 106, 10325-10333, doi:10.1029/2000JD900665, 2001.

Takamura, T.: Nakajima, And SKYNET community group: Overview of SKYNET and its Activities, Opt. Puray Apl., 37, 3303-3308, 2004.

Takamura, T., Sugimoto, N., Shimizu, A., Uchiyama, A., Yamazake, A., Aoki, K., Nakajima, T., Sohn, B. J., and Takenaka, H.: Aerosol radiative characteristics at Gosan, Korea during the atmospheric brown cloud East Asian regional experiment 2005, J. Geophys. Res., 112, D22S36, doi:10.1029/2007JD008506, 2007.

Tsunematsu, N.: Observed dust storm in the Taklimakan Desert on April 13, Sci. Lett. Atmos., 1, 21-24, doi:10.2151/sola.2005006, 2005.

Uno, I., Amano, H., Emori, S., Kinoshita, K., Matsui, I., and Sugimoto, N.: Trans-Pacific yellow sand transport observed in April 1998: A numerical simulation, J. Geophys. Res.-Atmos., 106, 18331-18344, doi:10.1029/2000JD900748, 2001.

van der Werf, G. R., Randerson, J. T., Giglio, L., Collatz, G. J., Mu, M., Kasibhatla, P. S., Morton, D. C., DeFries, R. S., Jin, Y., and van Leeuwen, T. T.: Global fire emissions and the contribution of deforestation, savanna, forest, agricultural, and peat fires (19972009), Atmos. Chem. Phys., 10, 11707-11735, doi:10.5194/acp10-11707-2010, 2010.
Wang, H., Shi, G. Y., Teruo, A., Wang, B., and Zhao, T. L.: Radiative forcing due to dust aerosol over east Asia-north Pacific region during spring 2001, Chinese Sci. Bull., 49, 2212-2219, 2004.

Wang, H., Zhang, X. Y., Gong, S. L., Chen, Y., Shi, G. Y., and Li, W.: Radiative feedback of dust aerosols on the East Asian dust storms, J. Geophys. Res., 115, D23214, doi:10.1029/2009JD013430, 2010.

Wang, J., Xu, X., Henze, D K., Zeng, J., Ji, Q., Tsay, S., and Huang, J.: Top-down estimate of dust emissions through integration of MODIS and MISR aerosol retrievals with the GEOS-Chem adjoint model, Geophys. Res. Lett., 39, 142-148, doi:10.1029/2012GL051136, 2012.

Wang, X., Huang, J., Zhang, R., Chen, B., and Bi, J.: Surface measurement of aerosol properties over northwest China during ARM China 2008 deployment, J. Geophys. Res.-Atmos., 115, 2333-2338, doi:10.1016/j.jqsrt.2010.09.006, 2010.

Winker, D., Pelon, J., and McCormick, M.: Initial results from CALIPSO, 23rd International Laser Radar Conference, Nara, Japan, 2006.

Winker, D., Hunt, W., and McGill, M.: Initial performance assessment of CALIOP, Geophys. Res. Lett., 34, L19803, doi:10.1029/2007GL030135, 2007.

Ye, H., Zhang, R., Shi, J., Huang, J., Warren, G. S., and Fu., Q.: Black carbon in seasonal snow across northern Xinjiang in northwestern China, Environ. Res. Lett., 7, 044002, doi:10.1088/1748-9326/7/4/044002, 2012.

Zhang, X. Y., Gong, S. L., Zhao, T. L., Arimoto, R., Wang, Y. Q., and Zhou, Z. J.: Sources of Asian dust and role of climate change versus desertification in Asian dust emission, Geophys. Res. Lett., 30, 2272, doi:10.1029/2003GL018206, 2003.

Zhang, Y., Takahashi, M., and Guo, L.: Analysis of the East Asian Subtropical Westerly Jet Simulated by CCSR/NIES/FRCGC Coupled Climate System Model, J. Meteorol. Soc. Jpn., 86, 257278, doi:10.2151/jmsj.86.257, 2008.

Zhao, C., Liu, X., Leung, L. R., Johnson, B., McFarlane, S. A., Gustafson, W. I., Fast, J. D., and Easter, R.: The spatial distribution of mineral dust and its shortwave radiative forcing over North Africa: modeling sensitivities to dust emissions and aerosol size treatments, Atmos. Chem. Phys., 10, 8821-8838, doi:10.5194/acp-10-8821-2010, 2010.

Zhao, C., Liu, X., Ruby Leung, L., and Hagos, S.: Radiative impact of mineral dust on monsoon precipitation variability over West Africa, Atmos. Chem. Phys., 11, 1879-1893, doi:10.5194/acp11-1879-2011, 2011.

Zhao, C., Liu, X., and Leung, L. R.: Impact of the Desert dust on the summer monsoon system over Southwestern North America, Atmos. Chem. Phys., 12, 3717-3731, doi:10.5194/acp-12-37172012, 2012.

Zhao, C., Chen, S., Leung, L. R., Qian, Y., Kok, J. F., Zaveri, R. A., and Huang, J.: Uncertainty in modeling dust mass balance and radiative forcing from size parameterization, Atmos. Chem. Phys., 13, 10733-10753, doi:10.5194/acp-13-10733-2013, 2013. 
Zhao, T. L., Gong, S. L., Zhang, X. Y., and Mckendry, I. G.: Modeled size-segregated wet and dry deposition budgets of soil dust aerosol during ACE-Asia 2001: Implications for trans-Pacific transport, J. Geophys. Res., 108, 8665, doi:10.1029/2002JD003363, 2003.
Zhao, T. L., Gong, S. L., Zhang, X. Y., Blanchet, J. P., McKendry, I. G., and Zhou, Z. J.: A simulated climatology of Asian dust aerosol and its trans-Pacific transport, Part I: Mean climate and validation, J. Clim., 19, 88-103, 2006. 